\title{
CONTRIBUTION TO THE STUDY OF ADRIATIC ISLAND FLORA: VASCULAR PLANT SPECIES DIVERSITY IN THE CROATIAN ISLAND OF OLIB
}

\author{
Milenko Milović ${ }^{*}$, Sanja Kovačić ${ }^{2}$, Nenad Jasprica ${ }^{3}$ \\ \& Vanja Stamenković ${ }^{2}$ \\ ${ }^{1}$ Antun Vrančić Grammar School, Put Gimnazije 64, HR-22000 Šibenik, Croatia \\ (*e-mail: milenko.milovic@si.t-com.hr) \\ ${ }^{2}$ Botanical Garden, Department of Biology, Faculty of Science, University of Zagreb, \\ Marulićev trg 9a, HR-10000 Zagreb, Croatia \\ ${ }^{3}$ Institute for Marine and Coastal Research, University of Dubrovnik, P.O. Box 83, \\ HR-20000 Dubrovnik, Croatia
}

Milović, M., Kovačić, S., Jasprica, N. \& Stamenković, V.: Contribution to the study of Adriatic island flora: Vascular plant species diversity in the Croatian Island of Olib. Nat. Croat., Vol. 25, No. 1, 25-54, 2016, Zagreb.

This paper is a first contribution to knowledge of the vascular plant species diversity of the NE Adriatic Island of Olib $\left(26.13 \mathrm{~km}^{2}\right)$. The total vascular flora of the island comprises 465 taxa of native and naturalised vascular plants, and 69 commonly cultivated taxa. The Mediterranean character of Olib flora is reflected by a large proportion of taxa belonging to the families Poaceae, Fabaceae and Asteraceae and a clear domination of the steno-Mediterranean plants, accompanied by a high percentage of therophytes. Although a low level of human influence is shown, the presence of exotic taxa outside cultivation has to be monitored due to their potential naturalisation. With this in mind, this article aimed at updating the statuses of the species Ipomoea quamoclit and Aptenia cordifolia in the checklist of Croatian vascular plants.

Key words: vascular plants, diversity, Island of Olib, eastern Adriatic, Mediterranean

Milović, M., Kovačić, S., Jasprica, N. \& Stamenković, V.: Prilog istraživanju flore jadranskih otoka: raznolikost vaskularnih biljaka na otoku Olibu. Nat. Croat., Vol. 25, No. 1, 25-54, 2016, Zagreb.

Ovaj rad prvi je prilog poznavanju raznolikosti vaskularne flore sjevernojadranskog otoka Oliba $(26,13$ km²), koja prema našem istraživanju obuhvaća 465 domaćih i udomaćenih biljnih svojta te 69 češće uzgajanih vrsta. Sredozemni karakter olipske flore ogleda se u velikoj zastupljenosti svojta iz porodica Poaceae, Fabaceae i Asteraceae, te prevladavanju steno-mediteranskih vrsta s visokim udjelom jednoljetnica (terofiti). Usprkos tome što je utjecaj čovjeka na otoku danas slab, pronašli smo više stranih vrsta izbjeglih iz uzgoja, što ukazuje na potrebu nadziranja njihovog budućeg širenja i mogućeg udomaćivanja. Smatramo potrebnim i da se vrste Ipomoea quamoclit i Aptenia cordifolia uključe u popis hrvatske flore.

Ključne riječi: vaskularne biljke, raznolikost, otok Olib, istočni Jadran, Sredozemlje

\section{INTRODUCTION}

The Mediterranean basin is the second largest biodiversity hotspot on Earth, the largest of the world's five Mediterranean-climate regions and third richest hotspot in terms of its plant diversity (Mittermeier et al., 2004). Circum-Mediterranean countries house about 25,000 plant species, almost one tenth of the world's vascular flora, $63 \%$ of which are endemic (Greuter, 1991; Médail \& QuÉzel, 1997, 1999). Nearly 10,000 islands of all sizes and 
origins exist in the Mediterranean basin and their wide ranges of altitudes, substrates and morphologies, as well as human activities, have resulted in the evolution of a highly diversified flora (e.g. Snogerup, 1985; Hulme, 2004; VogiatzaKis \& Griffiths, 2008). Generally, the islands are highly vulnerable ecosystems on which intense environmental fluctuations or human interference, even of a low intensity, can considerably affect the flora and vegetation (Vidal et al., 1998; PANitsa \& TZANOUdakis, 2010).

In the northern section of the Mediterranean Sea, the Adriatic basin forms its most important part. The Adriatic Sea comprises over 1,300 islands and isles, mostly located along its eastern, Croatian, coast, which are considered among the most diverse in the Mediterranean region. Generally, the Dalmatian coast could be also defined as a hotspot, but the data on its flora are still incomplete (MÉdaIL \& QuÉzeL, 1997). An estimation using the species-area relationship analysis (SAR) for 106 Adriatic islands (NiкоLIć et al., 2008), shows that 1,807 plant taxa grow on the Croatian islands, providing a heritage of biodiversity that must be bequeathed to future generations as a 'reservoir' available for the processes of biological evolution and for their ecological value. Most recent investigations (e.g. JASPRICA et al., 2015a) emphasized the importance of continuous floristic and phytocoenological investigations on the Croatian islands and islets, as done by local and foreign authors for other sites in the Adriatic basin and in some other Mediterranean countries (JERIČEvić et al., 2014 and references therein).

The total number of Croatian insular plant species is unknown, while there are still many islands and islets that have remained floristically unexplored. Among these is the subject of this study, the $18^{\text {th }}$ largest Croatian island, Olib (Fig. 1). The Island of Olib is a representative example of how island flora and vegetation could be rapidly changed by

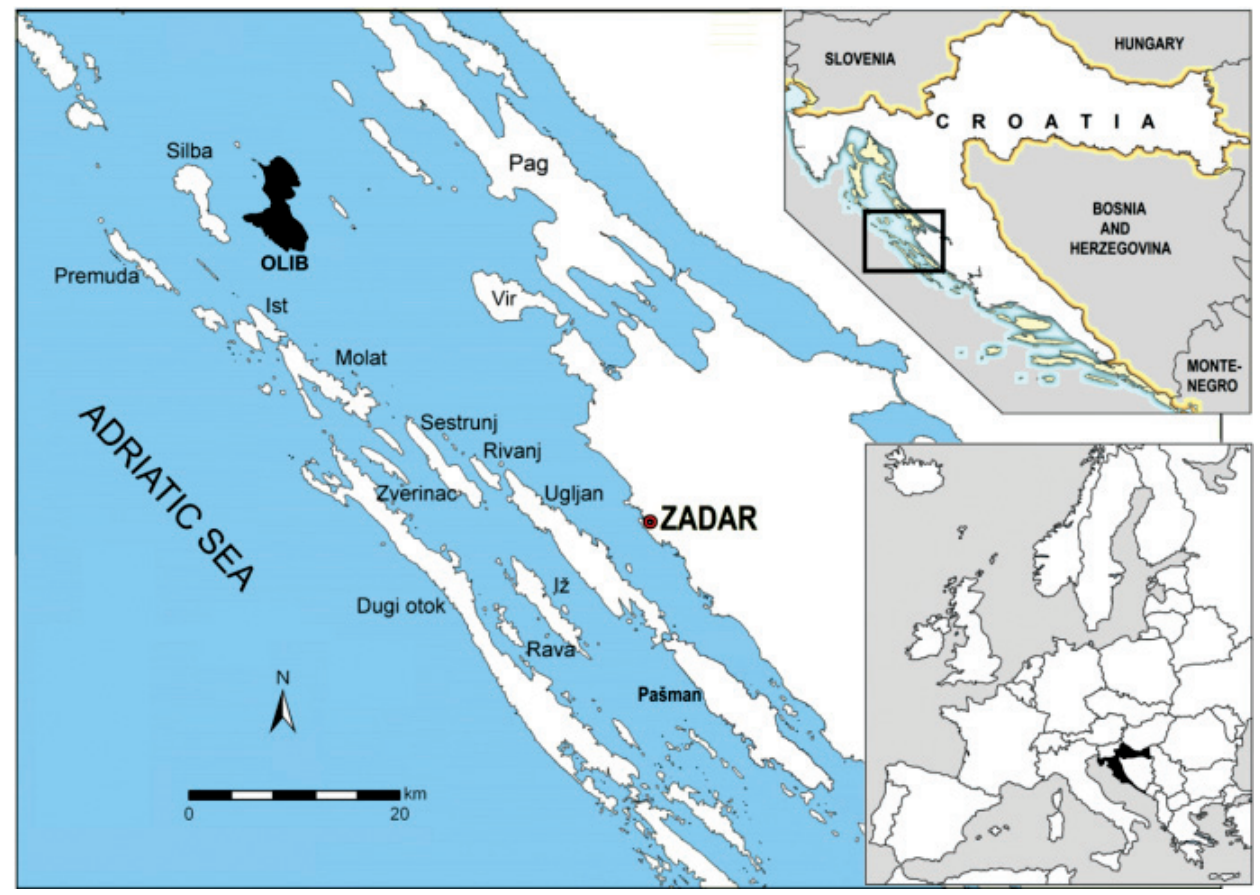

Fig. 1. Geographical position of the Island of Olib. 
humans: strong depopulation (emigration) during the past century, accompanied by the rapid abandonment of agriculture and livestock breeding, have caused the grasslands to become overgrown with woody vegetation in a relatively short period of time (BURA, 1955; MAgAš \& FARIČIĆ, 2002; Ivin, 2009).

The present paper provides, for the first time, floristic data on the Island of Olib, thus expanding the knowledge about the vascular flora of Croatian islands in general. The floristic data have been used to analyse life-form and chorological spectra, assess the species-area relationship, occurrence of rare plants and island specialists, as well as risk of alien plant invasion.

\section{Study area}

The Island of Olib (surface area $26.13 \mathrm{~km}^{2}$, perimeter $34.5 \mathrm{~km}$, max. altitude $74 \mathrm{~m}$ a.s.1.) belongs to the North-Adriatic group of islands and the western part of the Zadar archipelago (Fig. 1). The island is flat, stretching in the N-S direction and located $23.5 \mathrm{~km}$ from the mainland. It is $9.5 \mathrm{~km}$ long, but in the middle only $1.4 \mathrm{~km}$ wide, increasing to the maximum of $5.8 \mathrm{~km}$. Predominantly, Olib is built of Upper Cretaceous carbonates of an age ranging from Cenomanian to Senonian, and belongs to the Dinaric karst belt (Moro \& Jelaska, 1994; Vlahović \& Munda, 2012). Red Mediterranean soil or terra rossa is mostly developed on this geological substrate (MAGAš \& FARIčić, 2002). Although there are some sand and gravel beaches on the Island, the coast is predominantly low and rocky, with sea depths around it of 1-30 m. Precipitation drains almost exclusively through the underground and surface water flows appear only after extremely heavy rains. Surface retention of rainwater is very rare and related to locally pronounced limestone dolomitisation processes. Unlike most Croatian Adriatic islands, Olib has favourable hydrological conditions to accumulate significant quantities of groundwater in the karst aquifer, which fully complies with the sanitary quality of drinking water (VLAHOvić \& Munda, 2012).

No meteorological station exists on Olib. Though there are some data on the local measurements for the Island of Silba (aerial distance of $6 \mathrm{~km}$; BogDANović et al., 2013), the nearest official station of the Croatian Meteorological and Hydrological Service is situated in the town of Mali Lošinj (Island of Mali Lošinj, aerial distance from Olib approx. $27 \mathrm{~km}$ ). According to these comprehensive data (Croatian Meteorological and Hydrological Service, for 1985-2014), the average annual air temperature of the area is $15.8^{\circ} \mathrm{C}$ and precipitation averages $937.6 \mathrm{~mm} \mathrm{yr}^{-1}$. The highest daily average temperature is $24.9^{\circ} \mathrm{C}$ in July, and the lowest falls below $7.9^{\circ} \mathrm{C}$ in February. The absolute minimum temperature $\left(-4.4^{\circ} \mathrm{C}\right)$ was recorded on February $7^{\text {th }} 1991$ and December $26^{\text {th }} 1996$, and the absolute maximum $\left(37.4{ }^{\circ} \mathrm{C}\right)$ on August $3^{\text {rd }} 1998$. The largest rainfall is in October and November (average in each $122 \mathrm{~mm}$ ), and in December (average $102.8 \mathrm{~mm}$ ). In the period from June to August the total rainfall is $151.9 \mathrm{~mm}$. Northern winds prevail throughout the year. The highest wind speed is recorded in December (average $2.5 \mathrm{~m} \mathrm{~s}^{-1}$ ). This area has 2651.3 hours of sunshine per year. On average, the relative air humidity is $71 \%$ (Penzar et al., 2001). These data agree well with those reported for the neighbouring Island of Silba for 1991-2000 (BogDanović et al., 2013), while differing slightly from the City of Zadar for 1976-2006 (the average annual air temperature being $15.0^{\circ} \mathrm{C}$ and precipitation averages $860.4 \mathrm{~mm} \mathrm{yr}^{-1}$ ) (PANDŽA, 2010). On the basis of the phytoclimatic indices (Rivas-Martínez et al., 1999, 2004), the area is included in the Mediterranean pluviseasonal-oceanic bioclimatic region, lower meso-Mediterranean phytoclimatic belt, and upper subhumid ombrotype. 
Olib Island is a Croatian triple NATURA 2000-Ecological network-site (ANONYMOUs, 2013c): it is a part of the protected area important for birds (site code HR1000034 North part of the Zadar Archipelago), as well as for the species and habitats (HR2001280 Olib lands and HR3000052 Olib-underwater). Our research (JAsPRICA et al., 2016) revealed that at least 18 NATURA 2000 habitat types could be recognized on Olib Island.

From a biogeographic viewpoint, the study area is included in the Epiro-Dalmatian sector of the Adriatic province (RIvAs-Martínez et al., 2004), and phytogeographically, the island belongs to the Mediterranean vegetation zone of the Fraxino orni-Quercion ilicis alliance (Trinajstić, 1995; Biondi et al., 2014). The phytocoenotic diversity, with 33 plant associations within 23 vegetation classes, is prominent (JASPRICA et al., 2016), emphasizing the high biogeographical value of the study area. The mainly rocky coastal line is the site of an endemic association within the Crithmo maritimi-Staticetea vegetation class. The sandy substrates contain the Cakiletea maritimae communities. Not far from the sea, there are evergreen Quercus ilex woodlands, which can be considered as the potential vegetation type (the Myrto communis-Quercetum ilicis association).

\section{Human factor}

In the case of the Island of Olib, human activities are a factor that influences plant species diversity in general must be emphasized. The largest human immigration to the island came during the Turkish (Ottoman) invasions in 1476, when Olib was colonized from the Croatian hinterland (settlements around Vrlika, Zagora region). The newcomers did not accept the maritime way of living (sailing, fishing, using sea-food), but practised their traditional, continental land-farming practices (MAGAš \& FARIČIĆ, 2002; IvIN, 2009), thus changing the surface of the island immensely. The new inhabitants build vast dry stone walls, preparing the land for implementing extensive agriculture (vineyards, olivegroves, vegetable gardens). Large parts of the woods were cut down to obtain open pastures, intended for rearing the sheep. In such a manner, Olib was gradually cultivated up to the one-third of the total area (BurA, 1955; Ivin, 2009). After the First (1918), and then again Second World War (1945), many Olib people emigrated to the USA and Canada, abandoning the agricultural lands completely. Consequently, large areas under the dry grasslands (today mostly listed in the Annex I of the Habitat Directive) were gradually overgrown by woody vegetation, generally characterized by a significantly poorer flora (MAGAš \& FARIČić, 2002; JASPRICA et al., 2016).

Today, all permanent inhabitants live in the single settlement and harbour on the island, the village of Olib, which has existed since the Roman times (MAGAš \& FARIČić, 2002). It is located close to the sea, on the SW part of the Island $\left(44^{\circ} 22^{\prime} 46.9^{\prime \prime} \mathrm{N}, 14^{\circ} 46^{\prime} 39.9^{\prime \prime}\right.$ E). Olib roads are not suitable for the use of larger vehicles, but the whole Island is intersected with many kilometres of easily walkable, narrow earth-paths, bordered with impressive, tall dry stone walls. Numbering at the beginning of the 20th century almost 2500 inhabitants (IvIN, 2009), the Olib human population density gradually diminished: according to the 2011 census down to 140, while nowadays (personal communication) there are fewer than 80 permanent inhabitants. Current human activity, including touri$\mathrm{sm}$, is limited and restricted to the village of Olib and the sandy beaches nearby, while cutting of aging holm oak (Quercus ilex L.) trees is evident over the most of the island's surface area. Sheep were extensively reared until the period between the two World Wars, but for the last several decades have been scarce. In the outer zones of the Island there are some extensively managed olive groves and (mostly abandoned) fields, whereas within the village of Olib traditional gardening and some orchard-growing is practiced. 


\section{MATERIAL AND METHODS}

The study was carried out in May and August of 2015, using the standard methods (Nikolić, 2006; Nikolić et al., 1998). Whenever possible, a specimen of each taxon encountered in the flowering state was collected and pressed, but only if 10 or more individuals were present in a plant population. Herbarium specimens are deposited in the Herbarium Croaticum (ZA) of the Faculty of Science, University of Zagreb.

The study includes all noted indigenous and some common or prominent cultivated taxa. Accordingly, only naturalised and invasive plants (RICHARDSON et al., 2000) are included in the main flora list (Appendix 1). Plant species found exclusively in cultivation are shown in a separate list (Appendix 2), and are not included in the analysis of flora.

Taxa were determined using the standard keys, books and guides (Tutin et al., 19681980; Pignatti, 1982; Tutin et al., 1993; Domac, 1994; Delforge, 2006; Cullen \& Knees, 2011).

The nomenclature of plant taxa mainly follows Flora Croatica Database (Nikolić, 2016a), with the exception of some cultivated taxa, where European Garden Flora (CulLEN \& KNEES, 2011) was used. The taxa listed in Appendix 1 are given in alphabetical order of genera and species. Family, life form and chorological type (geoelement) were attributed to each taxon, while other, more local characteristics (endemic, threatened, statutorily protected, invasive) are given if they exist.

Biological form was verified in the field and denoted according to categories reported in Pignatti (1982), these being based on the classification of Raunkiaer (1934): Ch (Chamaephyta), G (Geophyta), H (Hemicryptophyta), P (Phanerophyta) and T (Therophyta).

Regarding chorological form, the division of the plants into floral elements and lower categories has been performed according to the classification of HoRvatić (1963) and Horvatić et al. (1967/1968). For some taxa, data from Fournier (1961) and Pignatti (1982) were also used following the aforementioned classifications of Horvatić (1963) and Honvatić et al. (1967/1968).

Statutorily strictly protected (SPR) taxa, defined by Croatian laws (Anonymous, 2013ab), are also denoted, as well as taxa that are considered invasive alien species (IAS; Boršıć et al., 2008) in Croatia. Endemic taxa are defined according to Nikolić et

Tab. 1. Taxonomic analysis of flora on the Island of Olib.

\begin{tabular}{|l|c|c|c|c|c|}
\hline \multirow{2}{*}{ Taxa } & \multirow{2}{*}{$\begin{array}{c}\text { Pterido- } \\
\text { phyta }\end{array}$} & \multirow{2}{*}{$\begin{array}{c}\text { Gymno- } \\
\text { spermae }\end{array}$} & \multicolumn{2}{|c|}{ Angiospermae } & \multirow{2}{*}{ Total } \\
\cline { 4 - 5 } & & & Dicotyledones & Monocotyledones & \\
\hline Families & 1 & 2 & 69 & 16 & 88 \\
\hline Genera & 1 & 3 & 209 & 60 & 273 \\
\hline Species & 0 & 1 & 324 & 99 & 430 \\
\hline Subspecies & 0 & 0 & 1 & 13 & 34 \\
\hline Varieties & 4 & 4 & 345 & 112 & 1 \\
\hline $\begin{array}{l}\text { No. of species and } \\
\text { infraspecific taxa }\end{array}$ & 0.86 & 0.86 & 74.19 & 24.09 & 100 \\
\hline \% of total flora & & & 20 & 0 & 105 \\
\hline
\end{tabular}


Tab. 2. Families with the highest number of taxa in the Island of Olib flora.

\begin{tabular}{|l|c|c|}
\hline Family & No. of taxa & \% of total flora \\
\hline Poaceae & 68 & 14.62 \\
\hline Fabaceae & 49 & 10.54 \\
\hline Asteraceae & 26 & 5.59 \\
\hline Cichoriaceae & 25 & 5.38 \\
\hline Lamiaceae & 21 & 4.52 \\
\hline Brassicaceae & 13 & 2.80 \\
\hline Scrophulariaceae & 13 & 2.80 \\
\hline Caryophyllaceae & 12 & 2.58 \\
\hline Apiaceae & 12 & 2.58 \\
\hline Rosaceae & 12 & 2.58 \\
\hline Chenopodiaceae & 12 & 2.58 \\
\hline Other families (77) & 202 & 43.44 \\
\hline Total (88 families) & 465 & 100.00 \\
\hline
\end{tabular}

al. (2015) and threatened species according to the Red Lists of Vascular Flora of Croatia (Nikolić, 2016b), Europe (Bilz et al., 2011, Anonymous, 2016a) and the Mediterranean (ANONYMous, 2016b).

\section{RESULTS}

During the floristic studies on the Island of Olib, 465 taxa (430 species, 34 subspecies and one variety) of native and naturalised vascular plants (Appendix 1) were noted, as well as 69 cultivated taxa (Appendix 2), altogether from 88 families and 273 genera (Tab. 1). Among them, the most represented families were: Poaceae (14.62 \%), Fabaceae (10.54 $\%)$, Asteraceae (5.59 \%), Cichoriaceae (5.38 \%) and Lamiaceae (4.52 \%) (Tab. 2).

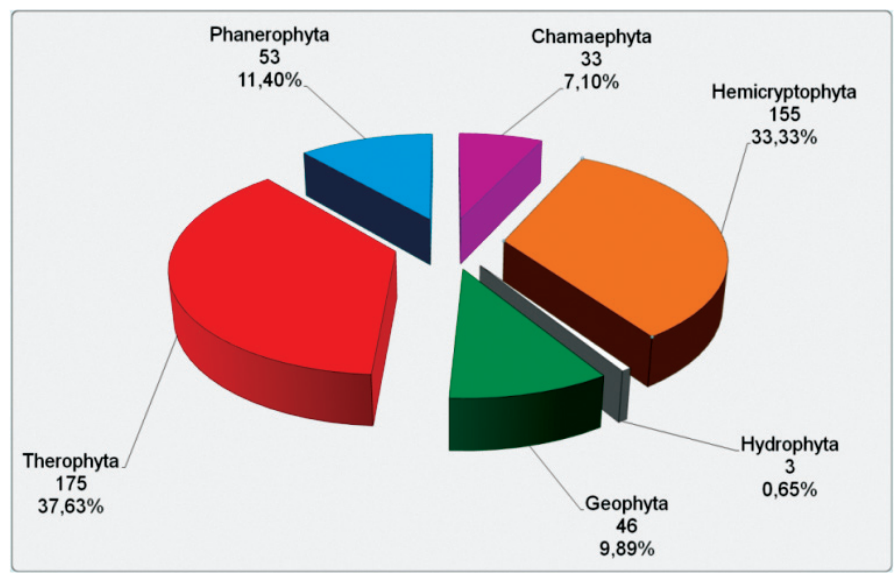

Fig. 2. Life-form spectrum in the Island of Olib flora. 
Genera with the highest number of taxa were Trifolium (13), Bromus (10) and Medicago (8), followed by Allium, Carex and Euphorbia (seven taxa in each genus), Amaranthus and Plantago (six taxa each), and Brachypodium, Lotus and Sedum (five taxa each).

The analysis of plant life forms showed that the Olib flora is dominated by therophytes (37.63\%) and hemicryptophytes (33.33\%) (Fig. 2).

The Mediterranean floral element (42.58 \%), mostly circum-Mediterranean plants, followed by a considerable proportion of Cosmopolitans (20.65\%) and South European plants (16.99\%) dominated on the Island (Tab. 3).

In total, 34 plant species found on the Island of Olib are statutorily strictly protected (SPR; Anonymous, 2013b). Nine species are considered to be endemic (Nikolić et al., 2015) (Tab. 4, Appendix 1), mostly belonging to the group of Illyrian-Adriatic endemics, while there are no real island endemics.

From the Croatian Red List, the category of Critically Endangered (CR) is assigned to one noted species (Elymus farctus (Viv.) Runemark ex Melderis). Three species (Carex

Tab. 3. Floral elements (geoelements) in the Island of Olib flora.

\begin{tabular}{|c|c|c|c|c|c|c|}
\hline \multicolumn{5}{|c|}{ Geoelements } & No. of taxa & $\%$ \\
\hline \multirow[t]{13}{*}{1.} & \multicolumn{4}{|c|}{ MEDITERRANEAN } & 198 & 42.58 \\
\hline & 1.1. & \multicolumn{3}{|c|}{ Circum-Mediterranean plants (CIME) } & 122 & 26.24 \\
\hline & 1.2. & \multicolumn{3}{|c|}{ West-Mediterranean plants (WME) } & 2 & 0.43 \\
\hline & 1.3. & \multicolumn{3}{|c|}{ East-Mediterranean plants (EME) } & 11 & 2.37 \\
\hline & 1.4. & \multicolumn{3}{|c|}{ Illyrian Mediterranean plants } & 22 & 4.73 \\
\hline & & A) & \multirow{2}{*}{\multicolumn{2}{|c|}{$\begin{array}{l}\text { Illyrian-South European plants (ILSEU) } \\
\text { Illyrian-Adriatic plants }\end{array}$}} & 9 & 1.94 \\
\hline & & B) & & & 13 & 2.80 \\
\hline & & & & Illyrian-Adriatic endemic plants (ILAE) & 7 & 1.51 \\
\hline & & & b) & Kvarner-Liburnian plants (KVLIB) & 1 & 0.22 \\
\hline & & & & Illyrian-Apennine plants (ILAP) & 5 & 1.08 \\
\hline & 1.5. & \multirow{3}{*}{\multicolumn{3}{|c|}{$\begin{array}{l}\text { Mediterranean-Atlantic plants (MEAT) } \\
\text { European Mediterranean plants (EUME) } \\
\text { Mediterranean-Pontic plants (MEPO) }\end{array}$}} & 25 & 5.38 \\
\hline & 1.6. & & & & 6 & 1.29 \\
\hline & 1.7. & & & & 10 & 2.15 \\
\hline \multirow[t]{3}{*}{2.} & \multicolumn{4}{|c|}{ SOUTH EUROPEAN } & 79 & 16.99 \\
\hline & 2.1. & \multirow{2}{*}{\multicolumn{3}{|c|}{$\begin{array}{l}\text { South European-Mediterranean plants (SEUME) } \\
\text { South European-Pontic plants (SEUPO) }\end{array}$}} & 63 & 13.55 \\
\hline & 2.2. & & & & 16 & 3.44 \\
\hline 3. & \multicolumn{4}{|c|}{ EAST EUROPEAN-PONTIC (EEUPO) } & 2 & 0.43 \\
\hline 4. & \multicolumn{4}{|c|}{ SOUTHEAST EUROPEAN (SEEU) } & 1 & 0.22 \\
\hline 5. & \multicolumn{4}{|c|}{ EUROPEAN (EURO) } & 11 & 2.37 \\
\hline 6. & \multicolumn{4}{|c|}{ EURASIAN (EUAS) } & 34 & 7.31 \\
\hline 7. & \multicolumn{4}{|c|}{ CIRCUM-HOLARKTIC PLANTS (CIHO) } & 3 & 0.65 \\
\hline 8. & \multicolumn{4}{|c|}{ WIDESPREAD PLANTS (WISP) } & 96 & 20.65 \\
\hline 9. & \multicolumn{4}{|c|}{ CULTIVATED and ADVENTITIOUS PLANTS (CUAD) } & 41 & 8.82 \\
\hline \multicolumn{5}{|c|}{ TOTAL } & 465 & 100.00 \\
\hline
\end{tabular}


Tab. 4. The number of plant taxa on the Island of Olib registered in Croatian Red List of Vascular Plants, statutorily strictly protected and invasive.

\begin{tabular}{|l|c|c|}
\hline Category & No. of taxa & \% of total flora (465) \\
\hline Endemic (END) & 9 & $1.94 \%$ \\
\hline Critically Endangered (CR) & 1 & $0.22 \%$ \\
\hline Endangered (EN) & 3 & $0.65 \%$ \\
\hline Vulnerable (VU) & 9 & $1.94 \%$ \\
\hline CR+EN+VU & 13 & $2.80 \%$ \\
\hline Nearly Threatened (NT) & 9 & $1.94 \%$ \\
\hline Data Deficient (DD) & 14 & $3.01 \%$ \\
\hline Least Concern (LC) & 7 & $1.51 \%$ \\
\hline NT+DD+LC & 30 & $6.45 \%$ \\
\hline Strictly protected (SPR) & 34 & $7.31 \%$ \\
\hline Invasive plants (IAS) & 16 & $3.44 \%$ \\
\hline
\end{tabular}

divisa Huds., C. extensa Gooden. and Glaucium flavum Crantz) are considered to be Endangered (EN), while nine are classified as Vulnerable (VU). From the lower categories of concern, nine taxa have been classified as Nearly Threatened (NT), seven are of Least Concern (LC) and 14 were found to be Data Deficient (DD) (Tab. 4, Appendix 1).

According to the global Red Lists, there are no taxa on the Island that can be considered directly threatened (categories CR, EN, VU). In the Red Lists for Europe (BILz et al., 2011; Anonymous, 2016a), the orchid Epipactis microphylla (Ehrh.) Sw. is considered Nearly Threatened (NT), while 51 taxa are of Least Concern (LC) and two are Data Deficient (DD). In the IUCN Red List for the Mediterranean region (ANONYMous, 2016b), seven species are listed as of Least Concern (LC). Being of low consideration, these data were not used in the final analysis of Olib flora.

Up to 16 taxa found on the Island are considered to be invasive (IAS) in Croatian territory (Tab. 4, Appendix 1).

\section{DISCUSSION}

Until this research, there was almost a complete lack of data concerning plant richness of the Island of Olib: 13 species are stated just in the work of BurA (1955). Nevertheless, Olib was, among other Croatian islands, included in the NATURA 2000 Ecological network (ANONYMOUs, 2013c).

During our field investigations 465 plant taxa were registered, representing $16.6 \%$ of the total flora of the entire Mediterranean area in Croatia (2797 taxa) or $9.2 \%$ of the total Croatian flora (5014 taxa), as recorded by Niкоlić et al., (2008) and Niкоцić (2016a), respectively. The largest proportion of taxa belong to Poaceae, Fabaceae and Asteraceae, which are among the families adapted best to the ecological conditions of the Mediterranean area, as confirmed by many floristic studies of eastern (e.g.PANDŽA, 2003; JASPRICA et al., 2006, 2015a; Jasprica \& Ruščić, 2013; Milović et al., 2013; PANDŽA \& Milović, 2015) 
and western Adriatic (CRISTOFOLINi et al., 1967), as well as other Mediterranean insular areas (f.e. Gianguzzi et al., 2006; Kougioumoutzis et al., 2012; Iliadou et al., 2014). The Mediterranean character of Olib flora is also reflected in the high proportions of Mediterranean plant taxa, in conjunction with the high percentage of therophytes.

According to a simplified analysis of the species/area relationship made for some eastern Adriatic islands, with surface areas between 11 and $26 \mathrm{~km}^{2}$ (Tab. 5), the investigated Island of Olib showed a relatively low variety of vascular plant taxa. Although, in general, surface area is considered the most influential explanatory variable of species richness in island biogeography (WhitTAKer \& Fernández-PAlacios, 2007), the roles of geographical position, geological history and palaeogeography determine the individual island floras as well (Nikolić et al., 2008; Iliadou et al., 2014). It has to be emphasized that Adriatic islands are very variable, not only according to their total area, but also according to their bioclimatic properties (autumn deciduous zone in the north; mixed and evergreen zones; spring deciduous zone on several open sea islands and islets), geomorphology (island height, terrain slopes and aspects, related soil characteristics, etc.), as well as the level of human impact (actual and historic land use, human population density, etc.). Finally, according to the equilibrium theory of island biogeography (MACARTHUR \& WiLsON, 1967), the number of vascular plant taxa on any island is in a state of dynamic equilibrium.

Abandonment of the traditional agriculture after the depopulation of the Island of Olib is in particular shown in the deserted terraced olive groves. A significant reduction in the vegetation and floristic diversity, as a result of secondary succession, was also previously shown on some Adriatic (Ljubičı́c, 2008; Sedlar, 2010) and Mediterranean islands (MACCHERINi et al., 2013).

The currently low proportion of alien species (3.4\%), frequently found mostly on disturbed places in the village of Olib within the Stellarietea mediae vegetation class (JAsPRICA et al., 2016), may be related to the low level of human activity. For example, although Mesembryanthemum crystallinum L. is considered to be an invasive alien plant in the Mediterranean (VILÀ et al., 2006) and the Adriatic islands (Boršıć et al., 2008), in the case of Olib it appears only in cultivation. Known invasive species Agave americana L., Carpobrotus acinaciformis (L.) L. Bolus and Opuntia vulgaris Miller, which in Olib are not invasive, nevertheless should be considered as potentially harmful. On the other hand,

Tab. 5. Comparison between the number of vascular plant taxa and surface areas of some eastern Adriatic islands.

\begin{tabular}{|l|c|c|l|}
\hline Island & Surface area $\left(\mathrm{km}^{2}\right)$ & No. of taxa & Reference \\
\hline Unije & 16.88 & 626 & TRINAJstić (1988) \\
\hline Vir & 22.08 & 623 & MiLović \& PANDžA (2016) \\
\hline Murter & 17.58 & 591 & PANDžA (1998) \\
\hline Šipan & 16.22 & 555 & Hećimović (1981) \\
\hline Olib & 26.14 & 534 & This study \\
\hline Silba & 14.27 & 532 & BoGDANović et al. (2013) \\
\hline Žirje & 15.08 & 451 & PANDŽA (2003) \\
\hline Drvenik Veli & 11.70 & 405 & BEDALOv (1976) \\
\hline Molat & 22.18 & 308 & DomAC (1963) \\
\hline
\end{tabular}


some of the otherwise exclusively cultivated taxa were found as "garden escapes" or "casuals" (Richardson et al., 2000), but they have not yet became naturalized (e.g. Albizia julibrissin Durazz., Bassia scoparia (L.) A. J. Scott, Cosmos bipinnatus Cav., Passiflora caerulea L., Petunia hybrida Vilm., Tanacetum parthenium (L.) Sch. Bip.), as was previously reported for some sites along the eastern Adriatic coast (TAFrA et al. 2012, and references therein). In addition, the present study revealed the presence of two alien plants which are already found to be invasive worldwide (Ipomoea quamoclit L. and Aptenia cordifolia (L. f.) N. E. Br.), found both in cultivation and as "casuals". The findings of exotic taxa and/or aliens outside cultivation, as well as at the same time monitoring the status of the currently 'just cultivated' taxa, seems to became an imperative, while they are potential candidates for possible naturalisation and subsequent invasiveness (VERLOove, 2006; Heywood \& SHARrock, 2013). With this in mind, this article aimed at updating the recent checklist of total vascular plant flora of Croatia (Nikolić, 2016a) with such species (Ipomoea quamoclit and Aptenia cordifolia).

On the Island of Olib we have not detected any of the real island specialists. The finding of Asplenium hybridum (Milde) Bange (Fig. 3), a stenoendemic fern restricted to the NE Adriatic islands (Nikolić et al., 2015), contributed to our present knowledge of the species range. We also found three endemics (Limonium cancellatum (Bernh. ex Bertol.) Kuntze, Lolium subulatum Vis. and Drypis spinosa L. ssp. jacquiniana Murb. et Wettst.) associated with halophilous or nitro-halophilous habitats (JAsPRICA et al., 2016), while others were related to the dry rocky grasslands and garrigue. Threatened taxa $(2.8 \%)$ are primarily distributed within the coastal brackish and halophilous communities, particularly on gravelly or sandy soils rich in nutrients, which are among the most threatened habitats in the eastern Adriatic (Alegro et al., 2004; PANDŽA et al., 2007; JASPRICA et al., 2015b).

In sum, the inventory of plant species diversity in the Island of Olib fills one more gap in the floristic information available, both for this previously floristically unexplored island, and the whole North Adriatic group of islands, thus adding to and complement-

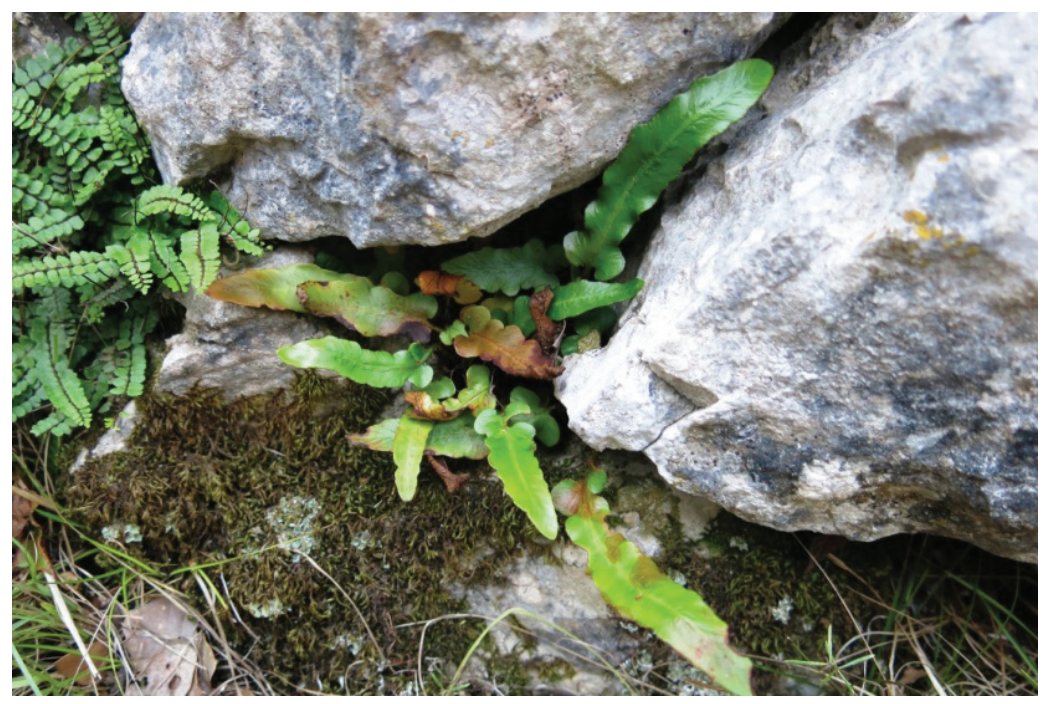

Fig. 3. Asplenium hybridum (Milde) Bange, a stenoendemic of the NE Adriatic islands, in the crevice of an old dry stone wall (photo by M. Milović). 
ing the case of the eastern Adriatic archipelago. Of particular note, the present study shows that the Island of Olib hosts significant plant species diversity and it is nowadays exposed to a low level of human influence, after six centuries of intensive agriculture. Further infringement upon the Island, with respect to the increase of activities carried out during the summer season (tourism), is not to be expected. However, the knowledge of the species diversity basically presented here is of crucial importance for management plans, which must ensure that land types, particularly coastal halophilous habitats and others included in the NATURA 2000 Ecological network, are used in a sustainable way.

\section{ACKNOWLEDGEMENTS}

Research funding came from the Natura Jadera Public Institution for Management of Protected Areas in the County of Zadar, Croatia. The authors thank the Croatian Meteorological and Hydrological Service for providing the meteorological data. Our thanks are also extended to Kate and Duje, the last two pupils of Olib Elementary School (closed in 2015), and their teacher, Mrs Tatjana Vukšević, for helping in plant collecting on their island (in early spring 2015).

Author contributions - S.K. planned the research; M.M. performed the analyses of flora; M.M. and N.J. led the writing, while all authors conducted the field sampling and critically revised the manuscript.

Received March 21, 2016

\section{REFERENCES}

Alegro, A., Biljaković, M., Bogdanović, S. \& Boršić, I., 2004: Psammo-halophytic vegetation on the largest sand area on Croatian coast: The Island of Mljet, southern Adriatic. Biologia 59, 435-445.

Anonymous, 2013a: Zakon o zaštiti prirode. [The Nature Protection Act]. Narodne novine (Official Gazette) $80 / 2013$.

Anonymous, 2013b: Pravilnik o strogo zaštićenim vrstama. [Ordinance of strictly protected species]. Narodne novine (Official Gazette) 144/2013.

Anonymous, 2013c: Uredba o ekološkoj mreži Republike Hrvatske. [Regulation of Ecological Network NATURA 2000 Croatia]. Narodne novine (Official Gazette) 124/2013.

Anonymous, 2016a: The IUCN Red List of Threatened Species in Europe: Version 2015-4. IUCN Species Survival Commission. (http://www.iucnredlist.org/initiatives/europe) [Last access: January 15th, 2016]

Anonymous, 2016b: The IUCN Red List of Threatened Species in the Mediterranean: Version $2015-4$. IUCN Species Survival Commission. (http://www.iucnredlist.org/initiatives/mediterranean) [Last access: January 15th, 2016]

Bedalov, M., 1976: Flora otoka Velog Drvenika. (The flora of the Veli Drvenik Island). Glasnik Prirodnjačkog Muzeja u Beogradu, B, 31, 97-110.

Bilz, M., Kell, S. P., Maxted, N. \& Lansdown, R. V., 2011: European Red List of Vascular Plants. Publications Office of the European Union, Luxembourg.

Biondi, E., Blasi, C., Allegrezza, M., Anzellotti, I., Azzella, M. M., Carli, E., Casavecchia, S., Copiz, R., del Vico, E., Facioni, L., Galdenzi, D., Gasparri, R., Lasen, C., Pesaresi, S., Poldini, L., Sburlino, G., Taffetani, F., Vagge, I., Zitti, S. \& Zivkovic, L., 2014: Plant communities of Italy: The Vegetation Prodrome. Plant Biosystems 148, 728-814.

Bogdanović, S., Župan, D. \& Mitić, B., 2013: Vaskularna flora otoka Silbe. (Vascular flora of the Island of Silba). In: Mužınić, J. \& Purger, J. J. (eds.), Otok Silba - prirodno i kulturno blago. (Island of Silba - Natural and Cultural Heritage), 81-94. University of Zadar.

Boršić, I., Milović, M., Dujmović, I., Bogdanović, S., Cigić, P., Rešetnik, I., Nikolić, T. \& Mitić, B., 2008 : Preliminary Check-list of invasive alien plant species (IAS) in Croatia. Natura Croatica 17(2), 55-71. 
BurA, D., 1955: Prebirni način gospodarenja u niskim privatnim šumama crnike (Quercus ilex) na Olibu. (Selective foresting in the private low forests of holm oak (Quercus ilex) on the Island of Olib). Šumarski list 5-6, 156-176.

Cristofolini, G., Lausi, D., Tarabocchia, M. \& Pignatti, S., 1967: Flora e vegetazione dell'isola di Pianosa, isole Tremiti. (Flora and vegetation of the Pianosa Island, Tremiti Islands). Giornale Botanica Italiana 101, 189-198.

Cullen, J. \& KneEs, S. G. (eds. in chief), 2011: The European Garden Flora, Vols. 1-5 (2 $2^{\text {nd }}$ ed.), Cambridge University Press.

Delforge, P. (ed.), 2006: Orchids of Europe, North Africa and the Middle East (2 $2^{\text {nd }}$ ed.). English translation, A. \& C. Black, London.

Domac, R., 1963: Flora otoka Molata. (Flora of the Island of Molat). Acta Botanica Croatica 22, 83-98.

DomAc, R., 1994: Flora Hrvatske - priručnik za određivanje bilja. (Flora of Croatia - manual for plant determination). Školska knjiga, Zagreb.

Fournier, P., 1961: Les Quatre Flores de la France. (Four Floras of France). Editions Paul Leghevalier, Paris.

Gianguzzi, L., Scuderi, L., \& PAsta, S., 2006: La flora vascolare dell'Isola di Marettimo (Arcipelago delle Egadi, Canale di Sicilia): aggiornamento ed analisi fitogeografica. (Vascular flora of the Island of Marettimo (Egadi Archipelago, Sicily Channel): phytogeographical updates and analyse). Webbia 61, 359-402.

Greuter, W., 1991: Botanical diversity, endemism, rarity, and extinction in the Mediterranean area: an analysis based on the published volumes of Med-Checklist. Botaniká Chroniká 10, 63-79.

Hećimović, M., 1981: Prilog i analiza flore otoka Šipana. (Contribution and analysis of the flora of Šipan Island). Acta Botanica Croatica 40, 205-227.

Heywood, V. H. \& Sharrock, S., 2013: European Code of Conduct for Botanic Gardens on Invasive Alien Species. Council of Europe, Strasbourg - Botanic Gardens Conservation International, Richmond.

Honvatić, S., 1963: Vegetacijska karta otoka Paga s općim pregledom vegetacijskih jedinica Hrvatskog primorja. (Vegetation map of the Island of Pag with a general overview of vegetation units of the Croatian coast). Prirodoslovna istraživanja JAZU 33, Acta Biologica 4, Zagreb.

Horvatić, S., Ilijanić, Lj. \& Marković-Gospodarić, LJ., 1967-1968: Biljni pokrov okolice Senja. (Vegetation of the Town of Senj sourroundings). Senjski zbornik 3, 298-322.

Hulme, P. E., 2004: Islands, invasions and impacts: a Mediterranean perspective. In: Fernández-Palacios, J. M. \& Morici, C. (eds.): Ecología Insular (Island Ecology), 359-383. Asociación Española De Ecología Terrestre.

Iliadou, E., Panitsa, M., Raus Th. \& Dimopoulos, P., 2014: Flora and factors affecting species diversity in the islet groups of the protected "Natura 2000" sites of the Amvrakikos Gulf and Mesolongi Lagoon (Ionian area, Greece). Willdenowia 44, 439-450.

Ivin, L. (ed.), 2009: Olib - otok, selo i ljudi. (Olib - Island, Village and People). „Braća hrvatskoga zmaja” \& Local committee of the Island of Olib, Zagreb - Olib.

Jasprica, N., Kovačıć, S. \& Ruščć, M., 2006: Flora and vegetation of Sveti Andrija Island, southern Croatia. Natura Croatica 15, 27-42.

Jasprica, N. \& Ruščić, M., 2013: Flora i vegetacija otočića Supetra - Cavtat, južna Hrvatska. (Flora and vegetation of the Supetar Isle (Cavtat, southern Croatia)). Hrvatska misao (Sarajevo) 46, 111-134.

Jasprica, N., Dolina, K. \& Milović, M., 2015a: Plant taxa and communities on three islets in south Croatia, NE Mediterranean. Natura Croatica 24, 191-213.

Jasprica, N., Milović, M. \& Romić, M., 2015b: Phytosociology and ecology of Cressa cretica L. (Convolvulaceae) on the eastern Adriatic coast. Hacquetia 14, 265-276.

Jasprica, N., Milović, M., Kovačić, S. \& Stamenković, V., 2016: Phytocoenotic diversity of the NE-Adriatic Island of Olib. Plant Sociology 53(1) (accepted for publication March 20th, 2016).

JeriČević, M., JeričEvić, N. \& Jasprica, N., 2014: Floristic novelties from the island of Korčula and peninsula of Pelješac (South Croatia). Natura Croatica 23, 241-253.

Kougioumoutzis, K., Tiniakou, A., Georgiou O. \& Georgiadis, T., 2012: Contribution to the flora of the South Aegean volcanic arc: Anafi island (Kiklades, Greece). Willdenowia 42, 127-141.

LJUBIČIĆ, I., 2008: Dinamika vegetacije i biljna raznolikost kamenjarskih pašnjaka na otoku Pagu. (Vegetation dynamics and plant diversity on the rocky pastures on the Island of Pag). Master's Thesis, Faculty of Science, University of Zagreb. 
MacArthur, R. H. \& Wilson, E. O., 1967: The theory of island biogeography. Princeton University Press.

Maccherini, S., Santi, E., Bonini, I., Amici, V., Pruscini, S., Palazzo, D. \& Selva, F. C., 2013: The impact of land abandonment on the plant diversity of olive groves. Biodiversity and Conservation 22(13-14), 3067-3083.

Magaš, D. \& FARIčić, J., 2002: Problemi suvremene socio-geografske preobrazbe otoka Oliba. (Problems of the Contemporary Socio-Geographic Transformation of the Island of Olib). Geoadria 7(2), 35-62.

MédAIL, F. \& QuÉzeL, P., 1997: Hot-spots analysis for conservation of plant biodiversity in the Mediterranean basin. Annals of Missouri Botanical Garden 84, 112-127.

Médail, F. \& Quézel, P., 1999: Biodiversity Hotsposts in the Mediterranean Basin: Setting Global Conservation Priorities. Conservation Biology 13, 1510-1513.

Milović, M. \& PAndžA, M., 2016: Flora i vegetacija otoka Vira (Flora and Vegetation of the Island of Vir). Book in press (data provided by authors).

Milović, M., Vukelja, N., PAndžA, M. \& Mitić, B., 2013: The vascular flora of Tribunj and nearby islets of Logorun and Lukovnik (Dalmatia, Croatia). Natura Croatica 22, 45-71.

Mittermeier, R.A., Gil, P.R., Hoffmann, M., Pilgrim, J., Brooks, T., Mittermeier, C.G., Lamoreux, J. \& Da Fonseca, G.A.B., 2004: Hotspots Revisited: Earth's Biologically Richest and Most Endangered Terrestrial Ecoregions. University of Chicago Press for Conservation International.

Moro, A. \& Jelaska, V., 1994: Upper Cretaceous peritidal deposits of Olib and Ist islands (Adriatic Sea, Croatia). Geologia Croatica 47(1), 53-65.

Nikolić, T., 2006: Flora: Handbook for inventory and monitoring. (Flora: priručnik za inventarizaciju i praćenje stanja). State Institute for Nature Protection, Zagreb.

Nikolić, T., Antonić, O., Alegro, A., Dobrović, I., Bogdanović, S., Liber, Z. \& Rešetnik, I., 2008: Plant species diversity of Adriatic islands: An introductory survey. Plant Biosystems 142, 435-445.

Nikolić, T. (ed.), 2016a: Flora Croatica Database. Available at http://hirc.botanic.hr/fcd. Division of Botany, Department of Biology, Faculty of Science, University of Zagreb. [Last access: March 5th, 2016]

Nikolić, T. (ed.), 2016b: Flora Croatica Red Book. Available at http://hirc.botanic.hr/fcd/CrvenaKnjiga/. Division of Botany, Department of Biology, Faculty of Science, University of Zagreb. [Last access: March 5th, 2016]

Nikolić, T., Milović, M., Bogdanović, S. \& Jasprica, N., 2015: Endemi u hrvatskoj flori. (Endemic plants in Croatian flora). Alfa d.d., Zagreb.

Nikolić, T., Bukovec, D., Šopf, J. \& Jelaska, S. D., 1998: Kartiranje flore Hrvatske - mogućnosti i standardi. (The mapping of Croatian flora - prospects and standards). Natura Croatica 7 (Suppl. 1), 1-62.

PAndžA, M. \& Milović, M., 2015: Flora of the islets near Pakoštane (Dalmatia, Croatia). Natura Croatica 24, 19-35.

PAndžA, M., 1998: Flora of the Island of Murter (central Adriatic). Acta Botanica Croatica 57, 99-122.

PANDŽA, M., 2003: Flora of the Island of Žirje and small islands around it (eastern Adriatic coast, Croatia). Acta Botanica Croatica 62(2), 115-139.

PANDŽA, M., 2010: Vegetacija Ista i Škarde s pripadajućim otočićima. (Vegetation of the islands of Ist and Škarda and the surrounding islets). In: FARIčIć, J. (ed.): Otoci Ist i Škarda. (Ist and Škarda Islets), 187-208. Sveučilište u Zadru.

PAndŽA, M., FranjIĆ, J. \& ŠKvorc, Ž., 2007: The saltmarsh vegetation on the east Adriatic coast. Biologia 62, 24-31.

Panitsa, M. \& Tzanoudakis, D., 2010: Floristic diversity on small islands and islets: Leros islets' group (East Aegean area, Greece). Phytologia Balcanica 16, 271-284.

Penzar, B., Penzar, I. \& Orlić, M., 2001: Vrijeme i klima hrvatskog Jadrana. (Weather and climate of the Croatian Adriatic). Nakladna kuća Dr. Feletar, Hrvatski hidrografski institut, Split - Zagreb.

Pignatti, S., 1982: Flora of Italy. (Flora d'Italia). I-III, Edagricole, Bologna.

Raunkiaer, C., 1934: The life forms of plants and statistical plant geography. Clarendon Press, Oxford.

Richardson, D. M., Pyšek, P., Rejmanek, M., Barbour, M. G., Panetta, F. D. \& West, C. J., 2000: Naturalization and invasion of alien plants: concepts and definitions. Diversity and Distributions 6, 93-107.

Rivas-Martínez, S., Penas, A. \& Díaz, T. E., 2004: Bioclimatic and Biogeographic Maps of Europe. University of León, Spain (http://www.globalbioclimatics.org/form/maps.htm) [last accessed on February 15, 2016]. 
Rivas-Martínez, S., SÁnchez-Mata, D. \& Costa, M., 1999: North American boreal and western temperate vegetation (Syntaxonomical synopsis of the potential natural plant communities of North America, II). Itinera Geobotanica 12, 5-316.

Sedlar, Z., 2010: Dinamika vegetacije na otoku Molatu u razdoblju od 1910. do 2010. godine. (Vegetation dynamics on the island of Molat between 1910 and 2010). PhD Dissertation. Faculty of Science, University of Zagreb.

Snogerup, S., 1985: The Mediterranean islands. In: Gomez-Campo, C. (ed.), Plant Conservation in the Mediterranean area, 159-173. Dr. W. Junk Publishers, Dordrecht.

TAfra, D., PAndžA, M. \& Milović, M., 2012: Vascular flora of the town of Omiš. Natura Croatica 21(2), 301-334.

Trinajstić, I., 1995: Plantgeographical division of forest vegetation of Croatia. Annales Forestales 20, 37-66.

Trinajstić, I., 1988: Prilog flori otoka Unija. (Contribution to the flora of the Island of Unije). Acta Botanica Croatica 47, 167-170.

Tutin, T. G., Burges, N. A., Chater, A. O., Edmondson, J. R. E., Heywood, V. H., Moore, D. M., Valentine, D. H., Walters, S. M. \& Webb, D. A. (eds.), 1993: Flora Europaea 1 (2 ${ }^{\text {nd }}$ ed.). Cambridge University Press.

Tutin, T. G., Heywood, V. H., Burges, N. A., Moore, D. M., Valentine, D. H., Walters, S. M. \& Webb, D. A. (eds.), 1968-1980: Flora Europaea 2 - 5. Cambridge University Press.

Verloove, F., 2006: Catalogue of neophytes in Belgium (1800-2005). Scripta Botanica Belgica 39. Meise, National Botanic Garden of Belgium.

Vidal, E., Medail, F., Tatoni, T., Vidal, P. \& Roche, P., 1998: Functional analysis of the newly established plants induced by nesting gulls on Riou Archipelago (Marseille, France). Acta Oecologica 19, 241-250.

Vilà, M., Tessier, M, Suehs, C. M., Brundu, G., Carta, L., Galanidis, A., Lambdon, P., Manca, M., Médail, F., Moragues, E., Traveset, A., Troumbis, A. Y. \& Hulme, P. E., 2006: Regional assessment of the impacts of plant invaders on vegetation structure and soil properties of Mediterranean islands. Journal of Biogeography 33, 853-861.

Vlahović, T. \& MundA, B., 2012: Karst aquifers on small islands - the Island of Olib, Croatia. Environmental Monitoring and Assessment 184, 6211-6228.

Vogiatzakis, I. N. \& Griffiths, G. H., 2008: Island Biogeography and Landscape Ecology. In: VogiatZAKIS, I. N., G. Pungetti \& A. MANnion (eds): Mediterranean Island Landscapes: natural and cultural approaches. Landscape Series, Vol. 9, 61-81. Springer Publishing.

Whittaker, R. J. \& Fernández-Palacios, J. M., 2007: Island biogeography: Ecology, evolution and conservation. Oxford University Press.

\title{
SAŽETAK
}

\section{Prilog istraživanju flore jadranskih otoka: raznolikost vaskularnih biljaka na otoku Olibu}

\author{
M. Milović, S. Kovačić, N. Jasprica \& V. Stamenković
}

Olib je veličinom 18 . hrvatski otok $\left(26,13 \mathrm{~km}^{2}\right)$ i najveći na kojemu dosada nisu provedena sustavna floristička istraživanja. Ovaj je rad stoga prvi prilog poznavanju raznolikosti vaskularnih biljaka toga sjevernojadranskog otoka. U povijesti poznat od rimskih vremena, izvorno šumoviti Olib stoljećima je naseljen. Posljednji veliki priljev stanovništva zbio se u 15. stoljeću, zbjegom hrvatskoga življa iz okolice Vrlike (Zagora) pred najezdom Turaka. Dolaskom na otok pridošlice krče šume hrasta crnike, kako bi se nastavile baviti tradicijskom poljoprivredom svoga kraja: poljodjelstvom i uzgojem ovaca. U trenutku najgušće napučenosti, na Olibu je živjelo nešto manje od 2500 stanovnika koji su se bavili poljoprivredom na gotovo trećini otoka, izgradivši nepregledne suhozide tijekom pripreme tla. Nakon Prvoga (1918.) i osobito Drugoga (1945.) svjetskog rata, s Oliba su u Sjevernu Ameriku odselile sto- 
tine obitelji te danas na otoku živi jedva 80 stalnih stanovnika. Napuštanje zemljoradnje i stočarstva vidljivo je na svakom koraku. Kako je daleko od kopna i prometno slabo povezan, Olib je i turistički nerazvijen (ne postoje prometnice pogodne za automobile niti prikladna infrastruktura) te su njegove prekrasne pješčane i šljunčane plaže poznate uglavnom ,,jahtašima".

Iako slabo istražen, Olib je trostruko Natura-područje: uključen u Ekološku mrežu Republike Hrvatske kao područje važno za ptice (HR1000034 Sjeverni dio zadarskog arhipelaga) te za vrste i staništa (HR2001280 Olib - kopno i HR3000052 Olib - podmorje).

Tijekom proljeća i ljeta 2015. godine, uz financijsku potporu Javne ustanove „Natura Jadera“ za upravljanje zaštićenim dijelovima prirode na području Zadarske županije, proveli smo sustavno popisivanje vaskularne flore na otoku Olibu. Istraživanje je provedeno diljem otoka i obuhvatilo je sva najznačajnija staništa, na kojima smo utvrdili 465 domaćih i udomaćenih biljnih svojta te 69 češće uzgajanih vrsta. Sredozemni karakter olipske flore ogleda se u velikoj zastupljenosti svojta iz porodica trava (Poaceae), mahunarki (Fabaceae) i glavočika (Asteraceae), dominaciji steno-mediteranskih vrsta te visokom udjelu jednogodišnjih vrsta (terofiti). Analiza podataka ukazuje na relativno nisku raznovrsnost biljnih vrsta za hrvatski otok te veličine, što vjerojatno treba pripisati napuštanju tradicijskog gospodarenja i prepuštanju otoka sukcesiji.

Analizom podataka na Olibu smo utvrdili postojanje 34 zakonom strogo zaštićene vrste i devet ilirsko-jadranskih endema, među kojima i rijetku paprat, križani jelenak (Asplenium hybridum). Jedna vrsta nalazi se na popisu kritično ugroženih (CR) vrsta hrvatske flore, tri na popisu ugroženih (EN), a devet je osjetljivih (VU). Śesnaest pronađenih vrsta nalazi se na popisu invazivnih u Republici Hrvatskoj, no većinu nismo uočili izvan privatnih vrtova i cvjetnjaka. Međutim, usprkos tome što je današnji antropogeni utjecaj na Olibu slab, pronalazak nekoliko stranih svojti izvan uzgoja ukazuje na potrebu nadziranja njihova budućeg širenja i mogućeg udomaćivanja. Dvije cijenjene uresnice, pantropsku jedoljetnicu Ipomoea quamoclit i mesnatu trajnicu Aptenia cordifolia, pronašli smo na Olibu izbjegle iz kulture te smatramo potrebnim uključiti ih u popis hrvatske flore (Flora Croatica Database) barem iz predostrožnosti, s obzirom na to da su u mnogim zemljama svijeta već zabilježene kao invazivne.

Naposljetku, želimo zahvaliti Kati i Duji, jedinim učenicima Osnovne škole „Zadarski otoci“ - Područni odjel „Otok Olib“ u šk. god. 2014/15., i njihovoj učiteljici, gospođi Tatjani Vukšević, koji su nam pomogli u inventariziranju biljaka na svome otoku. Njihovim odlaskom na dalje školovanje u Zadar, osnovna škola na Olibu u lipnju 2015. ponovo je zatvorena, na nepoznato razdoblje. 


\section{Appendix 1.}

The list of vascular plant taxa of the Island of Olib.

Life form: Ch - Chamaephyta, G - Geophyta, H - Hemicryptophyta, Hy - Hydrophyta, P - Phanerophyta, T - Therophyta; Chorological group: CIME - Circum-Mediteranean, WME - West-Mediterranean, EME - East-Mediterranean, ILSEU - Illyrian-South European, ILADE - Illyrian-Adriatic endemics, ILAP - Illyrian-Apennine, KVLIB - Kvarner-Liburnian, MEAT - Mediterranean-Atlantic,

EUME - European Mediterranean, MEPO - Mediterranean-Pontic, SEUME - South European-Mediterranean, SEUPO - South European-Pontic, EEUPO - East European-Pontic, SEEU - Southeast European, EURO - European, EUAS - Eurasian, CIHO - Circum-Holarctic, WISP - Widespread, CUAD - Cultivated\&Adventitious; Endemic\&Threatened taxa: end - Endemic; CR - Critically Endangered, EN - Endangered, VU - Vulnerable, NT - Near Threatened, LC - Least Concern, DD - Data Deficient; Protected taxa: SPR - strictly protected; Invasive plants (sensu BORŠIĆ et al., 2008): IAS

\begin{tabular}{|c|c|c|c|c|c|c|c|}
\hline 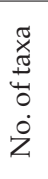 & Taxa & Family & 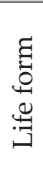 & 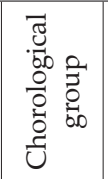 & 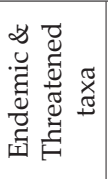 & 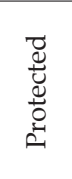 & 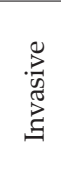 \\
\hline 1. & Aegilops geniculata Roth & Poaceae & $\mathrm{T}$ & CIME & & & \\
\hline 2. & Aegilops neglecta Req. ex Bertol. & Poaceae & $\mathrm{T}$ & CIME & NT & & \\
\hline 3. & Aetheorhiza bulbosa (L.) Cass. & Cichoriaceae & G & CIME & & & \\
\hline 4. & Agave americana $\mathrm{L}$. & Agavaceae & $\mathrm{P}$ & CUAD & & & \\
\hline 5. & Agrimonia eupatoria $\mathrm{L}$. & Rosaceae & $\mathrm{H}$ & $\mathrm{CIHO}$ & & & \\
\hline 6. & Agrostis capillaris L. & Poaceae & $\mathrm{H}$ & $\mathrm{CIHO}$ & & & \\
\hline 7. & Ailanthus altissima (Mill.) Swingle & Simaorubaceae & $\mathrm{P}$ & CUAD & & & IAS \\
\hline 8. & Ajuga genevensis L. & Lamiaceae & $\mathrm{H}$ & EUAS & & & \\
\hline 9. & Ajuga reptans $\mathrm{L}$. & Lamiaceae & $\mathrm{H}$ & EUAS & & & \\
\hline 10. & Alcea rosea $\mathrm{L}$. & Malvaceae & $\mathrm{H}$ & CUAD & & & \\
\hline 11. & Allium ampeloprasum $\mathrm{L}$. & Amaryllidaceae & G & CIME & & & \\
\hline 12. & Allium commutatum Guss. & Amaryllidaceae & G & CIME & & & \\
\hline 13. & Allium flavum $\mathrm{L}$. & Amaryllidaceae & G & CIME & & & \\
\hline 14. & Allium neapolitanum Cirillo & Amaryllidaceae & G & CIME & & & \\
\hline 15. & Allium paniculatum $\mathrm{L}$. & Amaryllidaceae & G & SEUME & & & \\
\hline 16. & Allium sphaerocephalon $\mathrm{L}$. & Amaryllidaceae & G & SEUME & & & \\
\hline 17. & Allium subhirsutum L. & Amaryllidaceae & G & CIME & & & \\
\hline 18. & Amaranthus cruentus L. & Amaranthaceae & $\mathrm{T}$ & CUAD & & & \\
\hline 19. & Amaranthus deflexus L. & Amaranthaceae & $\mathrm{T}$ & WISP & & & IAS \\
\hline 20. & Amaranthus graecizans L. & Amaranthaceae & $\mathrm{T}$ & MEPO & & & \\
\hline 21. & Amaranthus hybridus L. & Amaranthaceae & $\mathrm{T}$ & WISP & & & IAS \\
\hline 22. & Amaranthus powellii S.Watson & Amaranthaceae & $\mathrm{T}$ & CUAD & & & \\
\hline 23. & Amaranthus retroflexus L. & Amaranthaceae & $\mathrm{T}$ & WISP & & & IAS \\
\hline 24. & Anacamptys pyramidalis (L.) Rich. & Orchidaceae & G & EURO & NT & SPR & \\
\hline 25. & Anagallis arvensis L. & Primulaceae & $\mathrm{T}$ & WISP & & & \\
\hline 26. & Anchusa italica Retz. & Boraginaceae & $\mathrm{H}$ & CIME & & & \\
\hline 27. & Anemone hortensis L. & Ranunculaceae & G & CIME & & & \\
\hline
\end{tabular}




\begin{tabular}{|c|c|c|c|c|c|c|c|}
\hline 28. & Anthoxantum aristatum Boiss. & Poaceae & $\mathrm{T}$ & MEAT & DD & SPR & \\
\hline 29. & Anthoxantum odoratum L. & Poaceae & $\mathrm{H}$ & EUAS & & & \\
\hline 30. & $\begin{array}{l}\text { Anthyllis vulneraria L. ssp. praepropera } \\
\text { (A.Kern.) Bornm. }\end{array}$ & Fabaceae & $\mathrm{H}$ & EUME & & & \\
\hline 31. & Antirrhinum majus L. & Scrophulariaceae & $\mathrm{Ch}$ & CUAD & & & \\
\hline 32. & Arabis hirsuta (L.) Scop. & Brassicaceae & $\mathrm{H}$ & WISP & & & \\
\hline 33. & Arabis turrita L. & Brassicaceae & $\mathrm{H}$ & SEUME & & & \\
\hline 34. & Arbutus unedo L. & Ericaceae & $\mathrm{P}$ & CIME & & & \\
\hline 35. & Arctium minus Bernh. & Asteraceae & $\mathrm{H}$ & EURO & & & \\
\hline 36. & Arenaria leptoclados (Reichenb.) Guss. & Caryophyllaceae & $\mathrm{T}$ & EUAS & & & \\
\hline 37. & Aristolochia clematitis L. & Aristolochiaceae & $\mathrm{H}$ & SEUPO & & & \\
\hline 38. & Aristolochia rotunda $\mathrm{L}$. & Aristolochiaceae & G & CIME & & & \\
\hline 39. & Arthrocnemum fruticosum (L.) Moq. & Chenopodiaceae & $\mathrm{Ch}$ & SEUME & & & \\
\hline 40. & $\begin{array}{l}\text { Arthrocnemum macrostachyum (Moric.) } \\
\text { C. Koch }\end{array}$ & Chenopodiaceae & $\mathrm{Ch}$ & SEUME & & & \\
\hline 41. & Arum italicum Mill. & Araceae & G & CIME & & & \\
\hline 42. & Arundo donax $\mathrm{L}$. & Poaceae & G & CIME & & & \\
\hline 43. & Arundo micrantha Lam. & Poaceae & G & CIME & & & \\
\hline 44. & Asparagus acutifolius L. & Asparagaceae & G & CIME & & & \\
\hline 45. & Asphodelus aestivus Brot. & Xanthorrhoeaceae & G & CIME & & & \\
\hline 46. & Asphodelus fistulosus L. & Xanthorrhoeaceae & $\mathrm{H}$ & MEPO & & & \\
\hline 47. & Asplenium ceterach $\mathrm{L}$. & Aspleniaceae & $\mathrm{H}$ & SEUME & & & \\
\hline 48. & Asplenium hybridum (Milde) Bange & Aspleniaceae & $\mathrm{H}$ & KVLIB & end; NT & SPR & \\
\hline 49. & Asplenium ruta-muraria $\mathrm{L}$. & Aspleniaceae & $\mathrm{H}$ & $\mathrm{CIHO}$ & & & \\
\hline 50. & Asplenium trichomanes L. & Aspleniaceae & $\mathrm{H}$ & WISP & & & \\
\hline 51. & Aster squamatus (Spreng.) Hieron. & Asteraceae & $\mathrm{T}$ & CUAD & & & IAS \\
\hline 52. & Astragalus hamosus L. & Fabaceae & $\mathrm{T}$ & CIME & & & \\
\hline 53. & Atriplex patula $\mathrm{L}$. & Chenopodiaceae & $\mathrm{T}$ & WISP & & & \\
\hline 54. & $\begin{array}{l}\text { Atriplex prostrata Boucher ex DC. in } \\
\text { Lam. et DC. }\end{array}$ & Chenopodiaceae & $\mathrm{T}$ & WISP & & & \\
\hline 55. & Avena barbata Pott. ex Link & Poaceae & $\mathrm{T}$ & SEUPO & & & \\
\hline 56. & Avena sterilis L. & Poaceae & $\mathrm{T}$ & SEUPO & & & \\
\hline 57. & Ballota nigra L. ssp. foetida Hayek & Lamiaceae & $\mathrm{H}$ & SEUME & & & \\
\hline 58. & Beta vulgaris L. ssp. maritima (L.) Arcang. & Chenopodiaceae & $\mathrm{H}$ & MEAT & & & \\
\hline 59. & Biscutella cichoriifolia Loisel. & Brassicaceae & $\mathrm{T}$ & SEUME & & & \\
\hline 60. & Blackstonia perfoliata (L.) Huds. & Gentianaceae & $\mathrm{T}$ & MEAT & & & \\
\hline 61. & Brachypodium distachyon (L.) P.Beauv. & Poaceae & $\mathrm{T}$ & CIME & & & \\
\hline 62. & $\begin{array}{l}\text { Brachypodium phoenicoides (L.) Roem. et } \\
\text { Schult. }\end{array}$ & Poaceae & $\mathrm{H}$ & WME & $\mathrm{DD}$ & & \\
\hline 63. & $\begin{array}{l}\text { Brachypodium pinnatum (L.) P.Beauv. } \\
\text { ssp. rupestre (Host) Schübl. et M. } \\
\text { Martens }\end{array}$ & Poaceae & $\mathrm{H}$ & EUAS & & & \\
\hline
\end{tabular}




\begin{tabular}{|c|c|c|c|c|c|c|}
\hline 64. & Brachypodium retusum (Pers.) P.Beauv. & Poaceae & $\mathrm{H}$ & CIME & & \\
\hline 65. & $\begin{array}{l}\text { Brachypodium sylvaticum (Huds.) P. } \\
\text { Beauv. }\end{array}$ & Poaceae & $\mathrm{H}$ & EUAS & & \\
\hline 66. & Briza maxima $\mathrm{L}$ & Poaceae & $\mathrm{T}$ & CIME & & \\
\hline 67. & $\begin{array}{l}\text { Bromus erectus Huds. ssp. condensatus } \\
\text { (Hack.) Asch. et Graebn. }\end{array}$ & Poaceae & $\mathrm{H}$ & SEUME & & \\
\hline 68. & Bromus erectus Huds. ssp. erectus & Poaceae & $\mathrm{H}$ & SEUME & & \\
\hline 69. & Bromus hordeaceus L. ssp. hordeaceus & Poaceae & $\mathrm{T}$ & WISP & & \\
\hline 70. & $\begin{array}{l}\text { Bromus hordeaceus L. ssp. molliformis } \\
\text { (Lloyd) Maire et Weiller }\end{array}$ & Poaceae & $\mathrm{T}$ & SEUME & & \\
\hline 71. & Bromus intermedius Guss. & Poaceae & $\mathrm{T}$ & CIME & & \\
\hline 72. & Bromus madritensis L. & Poaceae & $\mathrm{T}$ & MEAT & & \\
\hline 73. & Bromus rigidus Roth & Poaceae & $\mathrm{T}$ & EEUPO & & \\
\hline 74. & Bromus scoparius L. & Poaceae & $\mathrm{T}$ & CIME & $\mathrm{DD}$ & SPR \\
\hline 75. & Bromus squarosus L. & Poaceae & $\mathrm{T}$ & SEUPO & & \\
\hline 76. & Bromus sterilis L. & Poaceae & $\mathrm{T}$ & WISP & & \\
\hline 77. & Bunias erucago L. & Brassicaceae & $\mathrm{T}$ & SEUME & & \\
\hline 78. & Bupleurum veronense Turra & Apiaceae & $\mathrm{T}$ & ILSEU & & \\
\hline 79. & Cakile maritima Scop. & Brassicaceae & $\mathrm{T}$ & WISP & & \\
\hline 80. & Calamintha glandulosa (Req.) Benth. & Lamiaceae & $\mathrm{H}$ & SEUME & & \\
\hline 81. & Calamintha nepetoides Jord. & Lamiaceae & $\mathrm{H}$ & SEUPO & & \\
\hline 82. & Calendula arvensis $\mathrm{L}$. & Asteraceae & $\mathrm{T}$ & SEUME & & \\
\hline 83. & Calendula officinalis $\mathrm{L}$. & Asteraceae & $\mathrm{T}$ & CUAD & & \\
\hline 84. & Calystegia sepium (L.) R.Br. & Convolvulaceae & $\mathrm{H}$ & WISP & & \\
\hline 85. & Campanula pyramidalis L. & Campanulaceae & $\mathrm{T}$ & ILADE & & \\
\hline 86. & Campanula rapunculus $\mathrm{L}$. & Campanulaceae & $\mathrm{H}$ & EUAS & & \\
\hline 87. & Campsis radicans (L.) Seen. & Bignoniaceae & $\mathrm{P}$ & CUAD & & \\
\hline 88. & Capsella bursa-pastoris (L.) Medik. & Brassicaceae & $\mathrm{T}$ & WISP & & \\
\hline 89. & Capsella rubella Reut. & Brassicaceae & $\mathrm{T}$ & CIME & & \\
\hline 90. & $\begin{array}{l}\text { Carduus micropterus (Borbás) Teyber } \\
\text { ssp. micropterus }\end{array}$ & Asteraceae & $\mathrm{H}$ & ILADE & end & SPR \\
\hline 91. & Carduus pycnocephalus L. & Asteraceae & $\mathrm{H}$ & CIME & DD & \\
\hline 92. & Carex distachya Desf. & Cyperaceae & $\mathrm{H}$ & CIME & & \\
\hline 93. & Carex distans $\mathrm{L}$. & Cyperaceae & $\mathrm{H}$ & SEUME & & \\
\hline 94. & Carex divisa Huds. & Cyperaceae & G & SEUME & EN & SPR \\
\hline 95. & Carex divulsa Stokes & Cyperaceae & $\mathrm{H}$ & WISP & & \\
\hline 96. & Carex extensa Gooden. & Cyperaceae & $\mathrm{H}$ & WISP & EN & SPR \\
\hline 97. & $\begin{array}{l}\text { Carex flacca Schreb. ssp. serrulata (Biv.) } \\
\text { Greuter }\end{array}$ & Cyperaceae & G & CIME & & \\
\hline 98. & Carex hallerana Asso & Cyperaceae & $\mathrm{H}$ & SEUME & & \\
\hline 99. & Carlina corymbosa $\mathrm{L}$. & Asteraceae & $\mathrm{H}$ & CIME & & \\
\hline 100. & Carpobrotus acinaciformis (L.) L. Bolus & Aizoaceae & $\mathrm{Ch}$ & CUAD & & \\
\hline
\end{tabular}




\begin{tabular}{|c|c|c|c|c|c|c|}
\hline 101. & Carthamus lanatus L. & Asteraceae & $\mathrm{T}$ & CIME & & \\
\hline 102. & Celtis australis L. & Ulmaceae & $\mathrm{P}$ & SEUME & & \\
\hline 103. & Centaurea solstitialis L. & Asteraceae & $\mathrm{H}$ & SEUPO & & \\
\hline 104. & Centaurium erythraea Rafn & Gentianaceae & $\mathrm{T}$ & WISP & & \\
\hline 105. & Centaurium pulchellum (Sw.) Druce & Gentianaceae & $\mathrm{T}$ & EUAS & & \\
\hline 106. & Centaurium spicatum (L.) Fritsch & Gentianaceae & $\mathrm{T}$ & CIME & & \\
\hline 107. & Centranthus ruber (L.) DC. & Valerianaceae & $\mathrm{Ch}$ & CUAD & & \\
\hline $108 .\left.\right|_{\varepsilon} ^{2}$ & $\begin{array}{l}\text { Cerastium pumilum Curtis ssp. } \\
\text { glutinosum (Fries) Jalas }\end{array}$ & Caryophyllaceae & $\mathrm{T}$ & WISP & & \\
\hline $109 . \mid \begin{array}{l}\mid l \\
l\end{array}$ & $\begin{array}{l}\text { Chaenorhinum minus (L.) Lange ssp. } \\
\text { litorale (Willd.) Hayek }\end{array}$ & Scrophulariaceae & $\mathrm{T}$ & ILAP & & \\
\hline 110. & Chenopodium album $\mathrm{L}$. & Chenopodiaceae & $\mathrm{T}$ & WISP & & \\
\hline 111. & Chenopodium strictum Roth & Chenopodiaceae & $\mathrm{T}$ & WISP & DD & \\
\hline 112. & Chondrilla juncea $\mathrm{L}$. & Cichoriaceae & $\mathrm{H}$ & EUAS & & \\
\hline 113. & Chrysopogon gryllus (L.) Trin. & Poaceae & $\mathrm{H}$ & MEPO & & \\
\hline 114. & Cichorium intybus L. & Cichoriaceae & $\mathrm{H}$ & WISP & & \\
\hline 115. & Cirsium arvense (L.) Scop. & Asteraceae & $\mathrm{T}$ & EUAS & & \\
\hline 1116. & Cirsium vulgare (Savi) Ten. & Asteraceae & $\mathrm{H}$ & EUAS & & \\
\hline 117. & Cistus incanus L. & Cistaceae & $\mathrm{P}$ & CIME & & \\
\hline 118. & Cistus monspeliensis L. & Cistaceae & $\mathrm{P}$ & CIME & & \\
\hline 119. & Cistus salvifolius L. & Cistaceae & $\mathrm{P}$ & CIME & & \\
\hline 120. & Clematis flammula $\mathrm{L}$. & Ranunculaceae & $\mathrm{P}$ & CIME & & \\
\hline 121. & Clematis vitalba $\mathrm{L}$. & Ranunculaceae & $\mathrm{P}$ & EURO & & \\
\hline $122 . \mathrm{S}_{\mathrm{s}}$ & $\begin{array}{l}\text { Convolvulus althaeoides L. ssp. tenuis- } \\
\text { simus (Sibth. et Sm.) Stace }\end{array}$ & Convolvulaceae & $\mathrm{H}$ & EME & & \\
\hline 123. & Convolvulus arvensis $\mathrm{L}$. & Convolvulaceae & G & WISP & & \\
\hline 124. & Conyza bonariensis (L.) Cronquist & Asteraceae & $\mathrm{T}$ & CUAD & & IAS \\
\hline 125. & Conyza canadensis (L.) Cronquist & Asteraceae & $\mathrm{T}$ & CUAD & & IAS \\
\hline 126. & Conyza sumatrensis (Retz.) E.Walker & Asteraceae & $\mathrm{T}$ & CUAD & & IAS \\
\hline 127. & $\begin{array}{l}\text { Coronilla emerus L. ssp. emeroides Boiss. } \\
\text { et Spruner }\end{array}$ & Fabaceae & $\mathrm{P}$ & EME & & \\
\hline 128. & Coronilla scorpioides (L.) Koch & Fabaceae & $\mathrm{T}$ & CIME & & \\
\hline 129. & Coronilla varia $\mathrm{L}$. & Fabaceae & $\mathrm{H}$ & EURO & & \\
\hline 130. & Crataegus monogyna Jacq. & Rosaceae & $\mathrm{P}$ & WISP & & \\
\hline 131. & Crepis neglecta $\mathrm{L}$. & Cichoriaceae & $\mathrm{T}$ & EUME & & \\
\hline 132. & Crepis sancta (L.) Babc. & Cichoriaceae & $\mathrm{T}$ & EME & & \\
\hline 133. & Crepis zacintha (L.) Babc. & Cichoriaceae & $\mathrm{T}$ & CIME & & \\
\hline 134. & Crithmum maritimum L. & Apiaceae & $\mathrm{Ch}$ & MEAT & & \\
\hline 135. & $\begin{array}{l}\text { Cupressus sempervirens L. (incl. C. } \\
\text { horizontalis Mill.) }\end{array}$ & Cupressaceae & $\mathrm{P}$ & CUAD & & \\
\hline 136. & Cuscuta campestris Yuncker & Cuscutaceae & $\mathrm{T}$ & CUAD & & IAS \\
\hline 137. & Cyclamen repandum Sibth. et Sm. & Primulaceae & G & EUME & NT & \\
\hline
\end{tabular}




\begin{tabular}{|c|c|c|c|c|c|c|c|}
\hline 138. & Cymodocea nodosa (Ucria) Asch. & Cymodoceaceae & Hy & MEAT & DD & SPR & \\
\hline 139. & Cynodon dactylon (L.) Pers. & Poaceae & G & WISP & & & \\
\hline 140. & Cynoglossum creticum Mill. & Boraginaceae & $\mathrm{T}$ & CIME & & & \\
\hline 141. & Cynosurus echinatus L. & Poaceae & $\mathrm{T}$ & SEUME & & & \\
\hline 142. & Dactylis glomerata L. ssp. glomerata & Poaceae & $\mathrm{H}$ & EUAS & & & \\
\hline 143. & $\begin{array}{l}\text { Dactylis glomerata L. ssp. hispanica } \\
\text { (Roth) Nyman }\end{array}$ & Poaceae & $\mathrm{H}$ & CIME & & & \\
\hline 144. & Datura inoxia Mill. & Solanaceae & $\mathrm{T}$ & CUAD & & & IAS \\
\hline 145. & Daucus carota L. ssp. carota & Apiaceae & $\mathrm{H}$ & EUAS & & & \\
\hline 146. & Daucus carota L. ssp. major (Vis.) Arcang. & Apiaceae & $\mathrm{H}$ & ILADE & & & \\
\hline 147. & Desmazeria marina (L.) Druce & Poaceae & $\mathrm{T}$ & MEAT & VU & SPR & \\
\hline 148. & Desmazeria rigida (L.) Tutin & Poaceae & $\mathrm{T}$ & MEAT & & & \\
\hline 149. & Dichanthium ischaemum (L.) Roberty & Poaceae & $\mathrm{H}$ & SEUME & & & \\
\hline 150. & Digitaria sanguinalis (L.) Scop. & Poaceae & $\mathrm{T}$ & WISP & & & \\
\hline 151. & Diplotaxis muralis (L.) DC. & Brassicaceae & $\mathrm{T}$ & WISP & & & \\
\hline 152. & Diplotaxis tenuifolia (L.) DC. & Brassicaceae & $\mathrm{H}$ & WISP & & & \\
\hline 153. & Dittrichia viscosa (L.) Greuter & Asteraceae & $\mathrm{H}$ & CIME & & & \\
\hline 154. & Dorycnium herbaceum Vill. & Fabaceae & $\mathrm{H}$ & SEUME & & & \\
\hline 155. & Dorycnium hirsutum (L.) Ser. & Fabaceae & $\mathrm{Ch}$ & CIME & & & \\
\hline 156. & Dorycnium pentaphyllum Scop. & Fabaceae & $\mathrm{Ch}$ & WME & & & \\
\hline 157. & $\begin{array}{l}\text { Drypis spinosa L. ssp. jacquiniana Murb. } \\
\text { et Wettst. }\end{array}$ & Caryophyllaceae & $\mathrm{Ch}$ & ILADE & end; LC & SPR & \\
\hline 158. & Ecballium elaterium (L.) A. Rich. & Cucurbitaceae & $\mathrm{Ch}$ & CIME & DD & & \\
\hline 159. & Echinaria capitata (L.) Desf. & Poaceae & $\mathrm{T}$ & CIME & DD & SPR & \\
\hline 160. & Echium italicum $\mathrm{L}$. & Boraginaceae & $\mathrm{H}$ & CIME & & & \\
\hline 161. & Echium plantagineum L. & Boraginaceae & $\mathrm{T}$ & MEAT & & & \\
\hline 162. & Elymus elongatus (Host) Runemark & Poaceae & $\mathrm{H}$ & SEUME & DD & & \\
\hline 163. & $\begin{array}{l}\text { Elymus farctus (Viv.) Runemark ex } \\
\text { Melderis }\end{array}$ & Poaceae & G & MEAT & $\mathrm{CR}$ & SPR & \\
\hline 164. & Elymus pycnanthus (Godr.) Melderis & Poaceae & G & CIME & NT & & \\
\hline 165. & Elymus repens (L.) Gould & Poaceae & G & WISP & & & \\
\hline 166. & Epipactis microphylla (Ehrh.) Sw. & Orchidaceae & G & EUAS & & SPR & \\
\hline 167. & Eragrostis cilianensis (All.) F.T.Hubb. & Poaceae & $\mathrm{T}$ & WISP & & & \\
\hline 168. & Erica arborea $\mathrm{L}$ & Ericaceae & $\mathrm{P}$ & CIME & & & \\
\hline 169. & Erigeron annuus (L.) Pers. & Asteraceae & $\mathrm{T}$ & CUAD & & & IAS \\
\hline 170. & Erodium malacoides (L.) L Hér. & Geraniaceae & $\mathrm{T}$ & CIME & & & \\
\hline 171. & Eryngium amethystinum L. & Apiaceae & $\mathrm{H}$ & ILSEU & & & \\
\hline 172. & Eryngium campestre L. & Apiaceae & $\mathrm{H}$ & SEUME & & & \\
\hline 173. & Euphorbia chamaesyce L. & Euphorbiaceae & $\mathrm{T}$ & SEUME & & & \\
\hline 174. & $\begin{array}{l}\text { Euphorbia characias L. ssp. wulfenii } \\
\text { (Hoppe ex Koch) A. M. Sm. }\end{array}$ & Euphorbiaceae & $\mathrm{Ch}$ & EME & & & \\
\hline
\end{tabular}




\begin{tabular}{|c|c|c|c|c|c|c|}
\hline 175. & Euphorbia helioscopia L. & Euphorbiaceae & $\mathrm{T}$ & WISP & & \\
\hline 176. & Euphorbia paralias L. & Euphorbiaceae & $\mathrm{Ch}$ & MEAT & DD & \\
\hline 177. & Euphorbia peplis L. & Euphorbiaceae & $\mathrm{T}$ & MEAT & & \\
\hline 178. & Euphorbia peplus L. & Euphorbiaceae & $\mathrm{T}$ & WISP & & \\
\hline 179. & Euphorbia pinea L. & Euphorbiaceae & $\mathrm{Ch}$ & CIME & & \\
\hline 180. & Fallopia convolvulus (L.) Á.Löve & Polygonaceae & $\mathrm{T}$ & WISP & & \\
\hline 181. & Festuca arundinacea Schreb. & Poaceae & $\mathrm{H}$ & EURO & & \\
\hline 182. & Festuca pratensis Huds. & Poaceae & $\mathrm{H}$ & WISP & & \\
\hline 183. & Ficus carica $\mathrm{L}$. & Moraceae & $\mathrm{P}$ & CUAD & & \\
\hline 184. & Filago vulgaris Lam. & Asteraceae & $\mathrm{T}$ & WISP & & \\
\hline 185. & Foeniculum vulgare Mill. & Apiaceae & $\mathrm{H}$ & CIME & & \\
\hline 186. & Fraxinus ornus L. & Oleaceae & $\mathrm{P}$ & SEUME & & \\
\hline 187. & Fumaria capreolata L. & Fumariaceae & $\mathrm{T}$ & MEAT & & \\
\hline 188. & Fumaria officinalis L. & Fumariaceae & $\mathrm{T}$ & WISP & & \\
\hline 189. & Galium aparine $\mathrm{L}$. & Rubiaceae & $\mathrm{T}$ & WISP & & \\
\hline 190. & Galium corrudifolium Vill. & Rubiaceae & $\mathrm{H}$ & SEUME & & \\
\hline 191. & Galium mollugo L. & Rubiaceae & $\mathrm{H}$ & EUAS & & \\
\hline 192. & Galium murale (L.) All. & Rubiaceae & $\mathrm{T}$ & CIME & & \\
\hline 193. & $\begin{array}{l}\text { Gastridium ventricosum (Gouan) Schinz } \\
\text { et Thell. }\end{array}$ & Poaceae & $\mathrm{T}$ & MEAT & & \\
\hline 194. & Geranium molle L. ssp. molle & Geraniaceae & $\mathrm{T}$ & WISP & & \\
\hline 195. & Geranium purpureum Vill. & Geraniaceae & $\mathrm{T}$ & SEUME & & \\
\hline 196. & Geranium robertianum L. & Geraniaceae & $\mathrm{T}$ & WISP & & \\
\hline 197. & Geranium rotundifolium L. & Geraniaceae & $\mathrm{T}$ & EUAS & & \\
\hline 198. & Gladiolus illyricus W.D.J.Koch & Iridaceae & G & SEUME & & SPR \\
\hline 199. & Glaucium flavum Crantz & Papaveraceae & $\mathrm{H}$ & MEAT & EN & SPR \\
\hline 200. & Hainardia cylindrica (Willd.) Greuter & Poaceae & $\mathrm{T}$ & CIME & VU & SPR \\
\hline 201. & Halimione portulacoides (L.) Aellen & Chenopodiaceae & $\mathrm{Ch}$ & WISP & & \\
\hline 202. & Hedera helix L. & Araliaceae & $\mathrm{P}$ & EURO & & \\
\hline 203. & Hedypnois cretica (L.) Dum.Cours. & Cichoriaceae & $\mathrm{T}$ & CIME & & \\
\hline 204. & Helichrysum italicum (Roth) G.Don & Asteraceae & $\mathrm{Ch}$ & CIME & & \\
\hline 205. & Heliotropium europaeum L. & Boraginaceae & $\mathrm{T}$ & MEPO & & \\
\hline 206. & Herniaria hirsuta L. & Caryophyllaceae & $\mathrm{T}$ & EURO & & \\
\hline 207. & Herniaria incana L. & Caryophyllaceae & $\mathrm{H}$ & SEUME & & \\
\hline 208. & Hieracium hoppeanum Schult. & Cichoriaceae & $\mathrm{H}$ & ILSEU & & \\
\hline 209. & Hieracium piloselloides Vill. & Cichoriaceae & $\mathrm{H}$ & ILSEU & & \\
\hline 210. & $\begin{array}{l}\text { Hieracium praealtum Vill. ex Gochnat } \\
\text { ssp. bauhinii (Besser) Petunn. }\end{array}$ & Cichoriaceae & $\mathrm{H}$ & EUAS & & \\
\hline 211. & Hippocrepis comosa $\mathrm{L}$. & Fabaceae & $\mathrm{H}$ & SEUME & & \\
\hline 212. & $\begin{array}{l}\text { Hordeum murinum L. ssp. leporinum } \\
\text { (Link) Arcang. }\end{array}$ & Poaceae & $\mathrm{T}$ & CIME & & \\
\hline
\end{tabular}




\begin{tabular}{|c|c|c|c|c|c|c|}
\hline 213. & Hypericum perforatum $\mathrm{L}$. & Clusiaceae & $\mathrm{H}$ & WISP & & \\
\hline 214. & Inula conyza DC. & Asteraceae & $\mathrm{H}$ & SEUPO & & \\
\hline 215. & Inula crithmoides L. & Asteraceae & $\mathrm{Ch}$ & MEAT & & \\
\hline 216. & Inula spiraeifolia L. & Asteraceae & $\mathrm{H}$ & SEUME & & \\
\hline 217. & Iris germanica L. & Iridaceae & G & CUAD & & SPR \\
\hline 218. & Iris illyrica Tomm. & Iridaceae & G & ILADE & end; LC & SPR \\
\hline 219. & Juncus acutus L. & Juncaceae & $\mathrm{H}$ & MEAT & & \\
\hline 220. & Juncus bufonius L. & Juncaceae & $\mathrm{T}$ & WISP & & \\
\hline 221. & Juncus compressus Jacq. & Juncaceae & G & WISP & & \\
\hline 222. & Juncus gerardi Loisel. & Juncaceae & G & WISP & & \\
\hline 223. & Juncus maritimus Lam. & Juncaceae & G & WISP & & \\
\hline 224. & Juniperus oxycedrus L. ssp. oxycedrus & Cupressaceae & $\mathrm{P}$ & CIME & & \\
\hline 225. & Juniperus phoenicea L. & Cupressaceae & $\mathrm{P}$ & CIME & & \\
\hline 226. & $\begin{array}{l}\text { Kickxia commutata (Bernh. ex Rchb.) } \\
\text { Fritsch }\end{array}$ & Scrophulariaceae & $\mathrm{H}$ & EUME & & \\
\hline 227. & Kickxia spuria (L.) Dumort. & Scrophulariaceae & $\mathrm{T}$ & EUAS & & \\
\hline 228. & Koelaria splendens C.Presl & Poaceae & $\mathrm{H}$ & SEUME & & \\
\hline 229. & Lactuca serriola $\mathrm{L}$ & Cichoriaceae & $\mathrm{H}$ & WISP & & \\
\hline 230. & Lactuca viminea (L.) J. et C.Presl & Cichoriaceae & $\mathrm{H}$ & SEUPO & & \\
\hline 231. & Lagurus ovatus L. & Poaceae & $\mathrm{T}$ & CIME & & \\
\hline 232. & Lathyrus aphaca L. & Fabaceae & $\mathrm{T}$ & SEUME & & \\
\hline 233. & Laurus nobilis L. & Lauraceae & $\mathrm{P}$ & CIME & & \\
\hline 234. & Lavatera arborea $\mathrm{L}$. & Malvaceae & $\mathrm{H}$ & EUME & & \\
\hline 235. & Leontodon crispus Vill. & Cichoriaceae & $\mathrm{H}$ & SEUME & & \\
\hline 236. & $\begin{array}{l}\text { Lepidium graminifolium L. ssp. suffrutico- } \\
\text { sum (L.) P.Monts. }\end{array}$ & Brassicaceae & $\mathrm{H}$ & SEUPO & & \\
\hline 237. & Lilium candidum $\mathrm{L}$. & Liliaceae & G & CUAD & & \\
\hline 238. & Limodorum abortivum (L.) Sw. & Orchidaceae & G & SEUME & & SPR \\
\hline 239. & Limonium bellidifolium (Gouan) Dumont & Plumbaginaceae & $\mathrm{H}$ & MEPO & & \\
\hline 240. & $\begin{array}{l}\text { Limonium cancellatum (Bernh. ex Bertol.) } \\
\text { Kuntze }\end{array}$ & Plumbaginaceae & $\mathrm{H}$ & ILAP & end & SPR \\
\hline 241. & Limonium narbonense Mill. & Plumbaginaceae & $\mathrm{H}$ & CIME & & \\
\hline 242. & Limonium oleifolium Miller & Plumbaginaceae & $\mathrm{H}$ & CIME & DD & \\
\hline 243. & Linaria angustissima (Loisel.) Borbás & Scrophulariaceae & $\mathrm{H}$ & SEUME & & \\
\hline 244. & Linaria vulgaris Mill. & Scrophulariaceae & $\mathrm{H}$ & EUAS & & \\
\hline 245. & Linum biennne Mill. & Linaceae & $\mathrm{H}$ & MEAT & & \\
\hline 246. & Lobularia maritima (L.) Desv. & Brassicaceae & $\mathrm{H}$ & CUAD & & \\
\hline 247. & Lolium multiflorum Lam. & Poaceae & $\mathrm{T}$ & CIME & & \\
\hline 248. & Lolium perenne $\mathrm{L}$. & Poaceae & $\mathrm{H}$ & EURO & & \\
\hline 249. & $\begin{array}{l}\text { Lolium rigidum Gaudin ssp. lepturoides } \\
\text { (Boiss.) Sennen et Mauricio }\end{array}$ & Poaceae & $\mathrm{T}$ & EME & & \\
\hline
\end{tabular}




\begin{tabular}{|c|c|c|c|c|c|c|}
\hline 250. & Lolium rigidum Gaudin ssp. rigidum & Poaceae & $\mathrm{T}$ & CIME & & \\
\hline 251. & Lolium subulatum Vis. & Poaceae & $\mathrm{T}$ & EME & end; DD & SPR \\
\hline 252. & Lonicera etrusca Santi & Caprifoliaceae & $\mathrm{P}$ & CIME & & \\
\hline 253. & Lonicera implexa Aiton & Caprifoliaceae & $\mathrm{P}$ & CIME & & \\
\hline 254. & Lophochloa cristata (L.) Hyl. & Poaceae & $\mathrm{T}$ & MEAT & & \\
\hline 255. & Lotus angustissimus L. & Fabaceae & $\mathrm{T}$ & SEUME & & \\
\hline 256. & Lotus corniculatus L. ssp. corniculatus & Fabaceae & $\mathrm{H}$ & WISP & & \\
\hline 257. & Lotus corniculatus L. ssp. hirsutus Rothm. & Fabaceae & $\mathrm{H}$ & SEUME & & \\
\hline 258. & Lotus cytisoides L. & Fabaceae & $\mathrm{Ch}$ & CIME & & \\
\hline 259. & Lotus glaber Mill. & Fabaceae & $\mathrm{H}$ & WISP & & \\
\hline 260. & Lotus ornithopodioides L. & Fabaceae & $\mathrm{T}$ & CIME & & \\
\hline 261. & Lythrum hyssopifolia L. & Lythraceae & $\mathrm{T}$ & WISP & & \\
\hline 262. & Malva neglecta Wallr. & Malvaceae & $\mathrm{T}$ & WISP & & \\
\hline 263. & Malva nicaensis All. & Malvaceae & $\mathrm{H}$ & CIME & & \\
\hline 264. & Malva sylvestris $\mathrm{L}$. & Malvaceae & $\mathrm{H}$ & WISP & & \\
\hline 265. & Marrubium incanum Desr. & Lamiaceae & $\mathrm{H}$ & CIME & & \\
\hline 266. & Matricaria perforata Mérat & Asteraceae & $\mathrm{T}$ & WISP & & \\
\hline 267. & Matthiola incana (L.) R. Br. & Brassicaceae & $\mathrm{Ch}$ & CUAD & & \\
\hline 268. & Medicago arabica (L.) Huds. & Fabaceae & $\mathrm{T}$ & WISP & & \\
\hline 269. & Medicago disciformis DC. & Fabaceae & $\mathrm{T}$ & CIME & & \\
\hline 270. & Medicago falcata $\mathrm{L}$. & Fabaceae & $\mathrm{H}$ & EUAS & & \\
\hline 271. & Medicago lupulina L. & Fabaceae & $\mathrm{T}$ & WISP & & \\
\hline 272. & Medicago minima (L.) Bartal. & Fabaceae & $\mathrm{T}$ & WISP & & \\
\hline 273. & Medicago orbicularis (L.) Bartal. & Fabaceae & $\mathrm{T}$ & CIME & & \\
\hline 274. & Medicago polymorpha L. & Fabaceae & $\mathrm{T}$ & SEUME & & \\
\hline 275. & Medicago sativa $\mathrm{L}$. & Fabaceae & $\mathrm{H}$ & WISP & & \\
\hline 276. & Melica ciliata L. & Poaceae & $\mathrm{H}$ & EUAS & & \\
\hline 277. & Melilotus indica (L.) All. & Fabaceae & $\mathrm{T}$ & CIME & & \\
\hline 278. & Melilotus officinalis (L.) Lam. & Fabaceae & $\mathrm{H}$ & EUAS & & \\
\hline 279. & Melissa officinalis L. & Lamiaceae & $\mathrm{H}$ & EME & & \\
\hline 280. & Mentha spicata L. & Lamiaceae & $\mathrm{H}$ & CUAD & & \\
\hline 281. & Mercurialis annua $\mathrm{L}$. & Euphorbiaceae & $\mathrm{T}$ & WISP & & \\
\hline 282. & Micromeria juliana (L.) Benth. ex Rchb. & Lamiaceae & $\mathrm{Ch}$ & CIME & & \\
\hline 283. & Mirabilis jalapa $\mathrm{L}$. & Nyctaginaceae & G & CUAD & & \\
\hline 284. & Misopates orontium (L.) Raf. & Scrophulariaceae & $\mathrm{T}$ & EUAS & & \\
\hline 285. & Morus alba L. & Moraceae & $\mathrm{P}$ & CUAD & & \\
\hline 286. & Muscari comosum (L.) Mill. & Asparagaceae & G & SEUME & & \\
\hline 287. & Muscari neglectum Guss. ex Ten. & Asparagaceae & G & SEUME & & \\
\hline 288. & Myrtus communis L. & Myrtaceae & $\mathrm{P}$ & CIME & & \\
\hline 289. & Narcissus tazetta L. & Amaryllidaceae & G & CIME & NT & \\
\hline
\end{tabular}




\begin{tabular}{|c|c|c|c|c|c|c|c|}
\hline 290. & Nerium oleander $\mathrm{L}$. & Apocynaceae & $\mathrm{P}$ & CUAD & & & \\
\hline 291. & Nigella damascena L. & Ranunculaceae & $\mathrm{T}$ & CIME & & & \\
\hline 292. & Oenanthe pimpinelloides L. & Apiaceae & $\mathrm{H}$ & MEAT & & & \\
\hline 293. & Oenanthe silaifolia M.Bieb. & Apiaceae & $\mathrm{H}$ & SEUPO & & & \\
\hline 294. & Oenothera biennis L. & Onagraceae & $\mathrm{H}$ & CUAD & & & IAS \\
\hline 295. & Olea europea L. & Oleaceae & $\mathrm{P}$ & CUAD & & & \\
\hline 296. & Olea europaea L. var. sylvestris Brot. & Oleaceae & $\mathrm{P}$ & CIME & & & \\
\hline 297. & Onopordum illyricum L. & Asteraceae & $\mathrm{H}$ & CIME & & & \\
\hline 298. & Ophrys bertolonii Moretti & Orchidaceae & G & SEUME & VU & SPR & \\
\hline 299. & $\begin{array}{l}\text { Ophrys scolopax Cav. ssp. cornuta } \\
\text { (Steven) E.G.Camus }\end{array}$ & Orchidaceae & G & MEPO & DD & SPR & \\
\hline 300. & Opuntia vulgaris Miller & Cactaceae & $\mathrm{P}$ & CUAD & & & \\
\hline 301. & Orchis tridentata Scop. & Orchidaceae & G & SEUME & VU & SPR & \\
\hline 302. & Origanum heracleoticum L. & Lamiaceae & $\mathrm{H}$ & EME & & & \\
\hline 303. & Orobanche minor Sm. & Orobanchaceae & $\mathrm{T}$ & SEUME & & & \\
\hline 304. & Oxalis articulata Savigny & Oxalidaceae & G & CUAD & & & \\
\hline 305. & Oxalis corniculata $\mathrm{L}$. & Oxalidaceae & $\mathrm{H}$ & WISP & & & \\
\hline 306. & Paliurus spina-christi Mill. & Rhamnaceae & $\mathrm{P}$ & ILSEU & & & \\
\hline 307. & Pallenis spinosa (L.) Cass. & Asteraceae & $\mathrm{T}$ & CIME & & & \\
\hline 308. & Papaver rhoeas L. & Papaveraceae & $\mathrm{T}$ & WISP & & & \\
\hline 309. & Parapholis incurva (L.) C.E.Hubb. & Poaceae & $\mathrm{T}$ & WISP & VU & SPR & \\
\hline 310. & Parietaria judaica L. & Urticaceae & $\mathrm{H}$ & SEUME & & & \\
\hline 311. & Parietaria officinalis L. & Urticaceae & $\mathrm{H}$ & SEUME & & & \\
\hline 312. & Partenocissus quinquefolia (L.) Planchon & Vitaceae & $\mathrm{P}$ & CUAD & & & IAS \\
\hline 313. & Petrorhagia saxifraga (L.) Link & Caryophyllaceae & $\mathrm{H}$ & SEUME & & & \\
\hline 314. & Phillyrea latifolia $\mathrm{L}$. & Oleaceae & $\mathrm{P}$ & CIME & & & \\
\hline 315. & Phillyrea media L. & Oleaceae & $\mathrm{P}$ & CIME & & & \\
\hline 316. & Phleum subulatum (Savi) Asch. et Grabn. & Poaceae & $\mathrm{T}$ & CIME & & & \\
\hline 317. & Physalis alkekengi $\mathrm{L}$. & Solanaceae & $\mathrm{H}$ & CUAD & & & \\
\hline 318. & Picris hieracioides L. & Cichoriaceae & $\mathrm{H}$ & EUAS & & & \\
\hline 319. & Picris hispidissima (Bartl.) Koch & Cichoriaceae & $\mathrm{H}$ & ILSEU & & & \\
\hline 320. & Pinus halepensis Mill. & Pinaceae & $\mathrm{P}$ & CIME & & & \\
\hline 321. & Piptatherum miliaceum (L.) Coss. & Poaceae & $\mathrm{H}$ & CIME & & & \\
\hline 322. & Pistacia lentiscus L. & Anacardiaceae & $\mathrm{P}$ & CIME & & & \\
\hline 323. & Plantago altissima $\mathrm{L}$. & Plantaginaceae & $\mathrm{H}$ & SEUME & & & \\
\hline 324. & Plantago coronopus L. ssp. coronopus & Plantaginaceae & $\mathrm{T}$ & EUAS & & & \\
\hline 325. & $\begin{array}{l}\text { Plantago coronopus L. ssp. weldenii } \\
\text { (Rchb.) Arcang. }\end{array}$ & Plantaginaceae & $\mathrm{T}$ & MEPO & & & \\
\hline 326. & Plantago holosteum Scop. & Plantaginaceae & $\mathrm{H}$ & SEUME & $\mathrm{LC}$ & & \\
\hline 327. & Plantago lanceolata $\mathrm{L}$. & Plantaginaceae & $\mathrm{H}$ & WISP & & & \\
\hline
\end{tabular}




\begin{tabular}{|c|c|c|c|c|c|c|c|}
\hline 328. & $\begin{array}{l}\text { Plantago major L. ssp. intermedia (Gilib.) } \\
\text { Lange }\end{array}$ & Plantaginaceae & $\mathrm{H}$ & WISP & & & \\
\hline 329. & Plumbago europaea L. & Plumbaginaceae & $\mathrm{Ch}$ & CIME & & & \\
\hline 330. & Poa annua $\mathrm{L}$. & Poaceae & $\mathrm{T}$ & WISP & $\mathrm{LC}$ & & \\
\hline 331. & Poa pratensis $\mathrm{L}$. & Poaceae & $\mathrm{H}$ & WISP & & & \\
\hline 332. & $\begin{array}{l}\text { Poa trivialis L. ssp. sylvicola (Guss.) H. } \\
\text { Lindb. }\end{array}$ & Poaceae & $\mathrm{H}$ & EUME & $\mathrm{LC}$ & & \\
\hline 333. & Polycarpon tetraphyllum (L.) L. & Caryophyllaceae & $\mathrm{T}$ & SEUME & & & \\
\hline 334. & Polygonum arenastrum Boreau & Polygonaceae & $\mathrm{T}$ & WISP & & & \\
\hline 335. & Polygonum aviculare $\mathrm{L}$. & Polygonaceae & $\mathrm{T}$ & WISP & & & \\
\hline 336. & Polygonum maritimum L. & Polygonaceae & $\mathrm{Ch}$ & MEPO & & & \\
\hline 337. & Polypogon maritimus Willd. & Poaceae & $\mathrm{T}$ & CIME & NT & & \\
\hline 338. & Polypogon monspeliensis (L.) Desf. & Poaceae & $\mathrm{T}$ & WISP & NT & & \\
\hline 339. & Portulaca oleracea L. & Portulacaceae & $\mathrm{T}$ & WISP & & & \\
\hline 340. & Posidonia oceanica (L.) Delile & Zoosteraceae & Hy & CIME & DD & SPR & \\
\hline 341. & Potentilla detommasii Ten. & Rosaceae & $\mathrm{H}$ & SEEU & & & \\
\hline 342. & Potentilla recta $\mathrm{L}$ & Rosaceae & $\mathrm{H}$ & EUAS & & & \\
\hline 343. & Potentilla reptans $\mathrm{L}$. & Rosaceae & $\mathrm{H}$ & WISP & & & \\
\hline 344. & Prunella laciniata (L.) L. & Lamiaceae & $\mathrm{H}$ & SEUME & & & \\
\hline 345. & Prunus cerasifera Ehrh. & Rosaceae & $\mathrm{P}$ & CUAD & & & \\
\hline 346. & Prunus dulcis (Mill.) D.A.Webb & Rosaceae & $\mathrm{P}$ & CUAD & & & \\
\hline 347. & Prunus persica (L.) Batsch & Rosaceae & $\mathrm{P}$ & CUAD & & & \\
\hline 348. & Prunus spinosa L. & Rosaceae & $\mathrm{P}$ & EUAS & & & \\
\hline 349. & Punica granatum $\mathrm{L}$. & Punicaceae & $\mathrm{P}$ & CUAD & & & \\
\hline 350. & Quercus ilex L. & Fagaceae & $\mathrm{P}$ & CIME & & & \\
\hline 351. & Ranunculus acris L. & Ranunculaceae & $\mathrm{H}$ & WISP & & & \\
\hline 352. & Ranunculus muricatus L. & Ranunculaceae & $\mathrm{T}$ & CIME & & & \\
\hline 353. & Ranunculus parviflorus L. & Ranunculaceae & $\mathrm{T}$ & MEAT & & & \\
\hline 354. & Ranunculus sardous Crantz & Ranunculaceae & $\mathrm{T}$ & WISP & & & \\
\hline 355. & Reichardia picroides (L.) Roth & Cichoriaceae & $\mathrm{H}$ & CIME & & & \\
\hline 356. & Reseda alba L. & Resedaceae & $\mathrm{H}$ & CIME & & & \\
\hline 357. & Reseda phyteuma L. & Resedaceae & $\mathrm{T}$ & SEUME & & & \\
\hline 358. & Rhamnus alaternus $\mathrm{L}$. & Rhamnaceae & $\mathrm{P}$ & CIME & & & \\
\hline 359. & Robinia pseudoacacia L. & Fabaceae & $\mathrm{P}$ & CUAD & & & IAS \\
\hline 360. & $\begin{array}{l}\text { Romulea bulbocodium (L.) Sebast. et } \\
\text { Mauri }\end{array}$ & Iridaceae & G & CIME & & & \\
\hline 361. & Rosa sempervirens L. & Rosaceae & $\mathrm{P}$ & CIME & & & \\
\hline 362. & Rubia peregrina $\mathrm{L}$. & Rubiaceae & $\mathrm{P}$ & CIME & & & \\
\hline 363. & Rubus ulmifolius Schott & Rosaceae & $\mathrm{P}$ & MEAT & & & \\
\hline 364. & Rumex conglomeratus Murray & Polygonaceae & $\mathrm{H}$ & WISP & & & \\
\hline
\end{tabular}




\begin{tabular}{|c|c|c|c|c|c|c|}
\hline 365. & Rumex crispus L. & Polygonaceae & $\mathrm{H}$ & WISP & & \\
\hline 366. & Rumex pulcher $\mathrm{L}$. & Polygonaceae & $\mathrm{H}$ & SEUPO & & \\
\hline 367. & Ruscus aculeatus L. & Asparagaceae & $\mathrm{P}$ & CIME & $\mathrm{LC}$ & \\
\hline 368. & Ruta graveolens L. & Rutaceae & $\mathrm{Ch}$ & ILAP & & \\
\hline 369. & Sagina maritima G.Don & Caryophyllaceae & $\mathrm{T}$ & MEAT & & \\
\hline 370. & $\begin{array}{l}\text { Salicornia procumbens Sm. ssp. } \\
\text { procumbens }\end{array}$ & Chenopodiaceae & $\mathrm{T}$ & WISP & & \\
\hline 371. & Salsola kali L. & Chenopodiaceae & $\mathrm{T}$ & WISP & VU & SPR \\
\hline 372. & Salsola soda $\mathrm{L}$. & Chenopodiaceae & $\mathrm{T}$ & SEUPO & VU & SPR \\
\hline 373. & Salvia bertolonii Vis. & Lamiaceae & $\mathrm{H}$ & ILADE & & \\
\hline 374. & Salvia pratensis $\mathrm{L}$. & Lamiaceae & $\mathrm{H}$ & EURO & & \\
\hline 375. & Salvia verbenaca $\mathrm{L}$. & Lamiaceae & $\mathrm{H}$ & MEAT & & \\
\hline 376. & Sambucus ebulus L. & Caprifoliaceae & G & EURO & & \\
\hline 377. & Samolus valerandi $\mathrm{L}$. & Primulaceae & $\mathrm{H}$ & WISP & & \\
\hline 378. & $\begin{array}{l}\text { Sanguisorba minor Scop. ssp. muricata } \\
\text { Briq. }\end{array}$ & Rosaceae & $\mathrm{H}$ & SEUME & & \\
\hline 379. & Satureja montana $\mathrm{L}$. & Lamiaceae & $\mathrm{Ch}$ & SEUME & & \\
\hline 380. & Scirpus maritimus L. & Cyperaceae & G & WISP & NT & \\
\hline 381. & Scolymus hispanicus L. & Cichoriaceae & $\mathrm{H}$ & CIME & & \\
\hline 382. & Scorpiurus muricatus L. & Fabaceae & $\mathrm{T}$ & CIME & & \\
\hline 383. & Securigera cretica (L.) Lassen & Fabaceae & $\mathrm{T}$ & EME & & \\
\hline 384. & Securigera securidaca (L.) Degen et Dörfl. & Fabaceae & $\mathrm{T}$ & CIME & & \\
\hline 385. & Sedum acre L. & Crassulaceae & $\mathrm{Ch}$ & WISP & & \\
\hline 386. & Sedum album $\mathrm{L}$. & Crassulaceae & $\mathrm{Ch}$ & EUAS & & \\
\hline 387. & Sedum ochroleucum Chaix & Crassulaceae & $\mathrm{Ch}$ & SEUME & & \\
\hline 388. & Sedum sexangulare $\mathrm{L}$. & Crassulaceae & $\mathrm{Ch}$ & SEUME & & \\
\hline 389. & $\begin{array}{l}\text { Sedum telephium L. ssp. maximum (L.) } \\
\text { Krock. }\end{array}$ & Crassulaceae & $\mathrm{H}$ & EURO & & \\
\hline 390. & Sempervivum tectorum $\mathrm{L}$. & Crassulaceae & $\mathrm{Ch}$ & CUAD & & SPR \\
\hline 391. & Senecio vulgaris $\mathrm{L}$. & Asteraceae & $\mathrm{T}$ & WISP & & \\
\hline 392. & Sesleria autumnalis (Scop.) F.W.Schultz & Poaceae & $\mathrm{H}$ & ILSEU & & \\
\hline 393. & Setaria verticillata (L.) P.Beauv. & Poaceae & $\mathrm{T}$ & WISP & & \\
\hline 394. & Setaria viridis (L.) P.Beauv. & Poaceae & $\mathrm{T}$ & EUAS & & \\
\hline 395. & Sherardia arvensis $\mathrm{L}$. & Rubiaceae & $\mathrm{T}$ & WISP & & \\
\hline 396. & Sideritis romana $\mathrm{L}$. & Lamiaceae & $\mathrm{T}$ & CIME & & \\
\hline 397. & Silene latifolia Poir. & Caryophyllaceae & $\mathrm{H}$ & EUAS & & \\
\hline 398. & $\begin{array}{l}\text { Silene vulgaris (Moench) Garcke ssp. } \\
\text { angustifolia Hayek }\end{array}$ & Caryophyllaceae & $\mathrm{H}$ & SEUME & & \\
\hline 399. & Sisymbrium officinale (L.) Scop. & Brassicaceae & $\mathrm{T}$ & WISP & & \\
\hline 400. & Smilax aspera L. & Smilacaceae & $\mathrm{P}$ & CIME & & \\
\hline 401. & Smyrnium olusatrum L. & Apiaceae & $\mathrm{T}$ & MEAT & & \\
\hline
\end{tabular}




\begin{tabular}{|c|c|c|c|c|c|c|c|}
\hline 402. & Smyrnium perfoliatum $\mathrm{L}$. & Apiaceae & $\mathrm{H}$ & CIME & & & \\
\hline 403. & Solanum nigrum L. & Solanaceae & $\mathrm{T}$ & WISP & & & \\
\hline 404. & $\begin{array}{l}\text { Solanum villosum Mill. ssp. alatum } \\
\text { (Moench) Dostal }\end{array}$ & Solanaceae & $\mathrm{T}$ & EUAS & & & \\
\hline 405. & $\begin{array}{l}\text { Sonchus asper (L.) Hill ssp. glaucescens } \\
\text { (Jord.) Ball }\end{array}$ & Cichoriaceae & $\mathrm{T}$ & CIME & & & \\
\hline 406. & Sonchus oleraceus L. & Cichoriaceae & $\mathrm{T}$ & WISP & & & \\
\hline 407. & Sonchus tenerrimus L. & Cichoriaceae & $\mathrm{T}$ & CIME & & & \\
\hline 408. & Sorghum halepense (L.) Pers. & Poaceae & G & WISP & & & IAS \\
\hline 409. & Spartium junceum L. & Fabaceae & $\mathrm{P}$ & CIME & & & \\
\hline 410. & Spergularia salina J. Presl et C. Presl & Caryophyllaceae & $\mathrm{T}$ & WISP & & & \\
\hline 411. & $\begin{array}{l}\text { Stachys cretica L. ssp. salviifolia (Ten.) } \\
\text { Rech.f. }\end{array}$ & Lamiaceae & $\mathrm{H}$ & ILAP & & & \\
\hline 412. & Stachys thirkei K. Koch & Lamiaceae & $\mathrm{H}$ & EME & & & \\
\hline 413. & Stellaria media (L.) Vill. & Caryophyllaceae & $\mathrm{T}$ & WISP & & & \\
\hline 414. & Stipa bromoides (L.) Dörfl. & Poaceae & $\mathrm{H}$ & CIME & & & \\
\hline 415. & Suaeda maritima (L.) Dumort. & Chenopodiaceae & $\mathrm{T}$ & WISP & VU & SPR & \\
\hline 416. & Tamarix dalmatica Baum & Tamaricaceae & $\mathrm{P}$ & EME & & & \\
\hline 417. & Tammus communis $\mathrm{L}$. & Dioscoreaceae & G & SEUME & & & \\
\hline 418. & $\begin{array}{l}\text { Tanacetum cinerariifolium (Trevir.) Sch. } \\
\text { Bip. }\end{array}$ & Asteraceae & $\mathrm{Ch}$ & ILSEU & end & SPR & \\
\hline 419. & Taraxacum officinale Weber & Cichoriaceae & $\mathrm{H}$ & WISP & & & \\
\hline 420. & Teucrium chamaedrys L. & Lamiaceae & $\mathrm{Ch}$ & SEUPO & & & \\
\hline 421. & $\begin{array}{l}\text { Teucrium polium L. ssp. capitatum (L.) } \\
\text { Arcang. }\end{array}$ & Lamiaceae & $\mathrm{Ch}$ & MEPO & & & \\
\hline 422. & Theligonum cynocrambe $\mathrm{L}$. & Theligonaceae & $\mathrm{T}$ & SEUME & & & \\
\hline 423. & Thymus longicaulis C.Presl & Lamiaceae & $\mathrm{Ch}$ & ILAP & & & \\
\hline 424. & $\begin{array}{l}\text { Torilis arvensis (Huds.) Link ssp. } \\
\text { purpurea (Ten.) Hayek }\end{array}$ & Apiaceae & $\mathrm{T}$ & CIME & & & \\
\hline 425. & Tragopogon dubius L. & Cichoriaceae & $\mathrm{H}$ & SEUPO & & & \\
\hline 426. & Tragopogon porrifolius L. & Cichoriaceae & $\mathrm{H}$ & CIME & & & \\
\hline 427. & Tribulus terrestris L. & Zygophyllaceae & $\mathrm{T}$ & SEUME & & & \\
\hline 428. & Trifolium angustifolium L. & Fabaceae & $\mathrm{T}$ & CIME & & & \\
\hline 429. & Trifolium campestre Schreber & Fabaceae & $\mathrm{T}$ & WISP & & & \\
\hline 430. & Trifolium cherleri $\mathrm{L}$. & Fabaceae & $\mathrm{T}$ & SEUME & & & \\
\hline 431. & Trifolium fragiferum $\mathrm{L}$. & Fabaceae & $\mathrm{H}$ & WISP & & & \\
\hline 432. & Trifolium lappaceum L. & Fabaceae & $\mathrm{T}$ & CIME & & & \\
\hline 433. & $\begin{array}{l}\text { Trifolium repens L. ssp. prostratum } \\
\text { Nyman }\end{array}$ & Fabaceae & $\mathrm{H}$ & CIME & & & \\
\hline 434. & Trifolium repens L. ssp. repens & Fabaceae & $\mathrm{H}$ & WISP & & & \\
\hline 435. & Trifolium resupinatum $\mathrm{L}$. & Fabaceae & $\mathrm{T}$ & MEPO & VU & SPR & \\
\hline 436. & Trifolium scabrum L. & Fabaceae & $\mathrm{T}$ & CIME & & & \\
\hline
\end{tabular}




\begin{tabular}{|c|c|c|c|c|c|c|c|}
\hline 437. & Trifolium squamosum L. & Fabaceae & $\mathrm{T}$ & CIME & & & \\
\hline 438. & Trifolium stellatum $\mathrm{L}$. & Fabaceae & $\mathrm{T}$ & CIME & & & \\
\hline 439. & Trifolium striatum L. & Fabaceae & $\mathrm{T}$ & EUAS & & & \\
\hline 440. & Trifolium tomentosum $\mathrm{L}$. & Fabaceae & $\mathrm{T}$ & CIME & & & \\
\hline 441. & Ulmus minor Miller & Ulmaceae & $\mathrm{P}$ & WISP & & & \\
\hline 442. & $\begin{array}{l}\text { Urospermum dalechampii (L.) Scop. ex } \\
\text { F.W.Schmidt }\end{array}$ & Cichoriaceae & $\mathrm{H}$ & CIME & & & \\
\hline 443. & $\begin{array}{l}\text { Urospermum picroides (L.) Scop. ex } \\
\text { F.W.Schmidt }\end{array}$ & Cichoriaceae & $\mathrm{T}$ & CIME & & & \\
\hline 444. & Urtica dioica $\mathrm{L}$. & Urticaceae & $\mathrm{H}$ & WISP & & & \\
\hline 445. & Valantia muralis L. & Rubiaceae & $\mathrm{T}$ & CIME & & & \\
\hline 446. & Verbascum blattaria $\mathrm{L}$. & Scrophulariaceae & $\mathrm{H}$ & SEUPO & & & \\
\hline 447. & Verbascum phoeniceum L. & Scrophulariaceae & $\mathrm{T}$ & SEUPO & & & \\
\hline 448. & Verbascum sinuatum L. & Scrophulariaceae & $\mathrm{H}$ & CIME & & & \\
\hline 449. & Verbena officinalis $\mathrm{L}$. & Verbenaceae & $\mathrm{H}$ & WISP & & & \\
\hline 450. & Veronica arvensis L. & Scrophulariaceae & $\mathrm{T}$ & EUAS & & & \\
\hline 451. & Veronica persica Poir. & Scrophulariaceae & $\mathrm{T}$ & WISP & & & IAS \\
\hline 452. & Veronica polita Fr. & Scrophulariaceae & $\mathrm{T}$ & EUAS & & & \\
\hline 453. & Viburnum tinus L. & Caprifoliaceae & $\mathrm{P}$ & CIME & & & \\
\hline 454. & Vicia hybrida L. & Fabaceae & $\mathrm{T}$ & CIME & & & \\
\hline 455. & Vicia parviflora Cav. & Fabaceae & $\mathrm{T}$ & CIME & & & \\
\hline 456. & Vicia sativa $\mathrm{L}$. & Fabaceae & $\mathrm{T}$ & WISP & & & \\
\hline 457. & Vicia tenuissima (M.Bieb.) Schinz et Thell. & Fabaceae & $\mathrm{T}$ & SEUME & & & \\
\hline 458. & Vicia villosa Roth ssp. varia (Host) Corb. & Fabaceae & $\mathrm{T}$ & EEUPO & & & \\
\hline 459. & Vinca major L. & Apocynaceae & $\mathrm{Ch}$ & CUAD & & & \\
\hline 460. & $\begin{array}{l}\text { Vincetoxicum hirundinaria Medik. ssp. } \\
\text { adriaticum (Beck) Markgr. }\end{array}$ & Asclepiadaceae & $\mathrm{H}$ & ILSEU & end; LC & SPR & \\
\hline 461. & $\begin{array}{l}\text { Viola suavis M.Bieb. ssp. adriatica } \\
\text { (Freyn) Haesler }\end{array}$ & Violaceae & $\mathrm{H}$ & ILADE & end & SPR & \\
\hline 462. & Vitex agnus-castus L. & Verbenaceae & $\mathrm{P}$ & CIME & & & \\
\hline 463. & Vitis vinifera $\mathrm{L}$. & Vitaceae & $\mathrm{P}$ & CUAD & & & \\
\hline 464. & Vulpia ciliata Dumort. & Poaceae & $\mathrm{T}$ & SEUME & & & \\
\hline 465. & Zannichellia palustris L. & Zannichelliaceae & Hy & WISP & & & \\
\hline
\end{tabular}




\section{Appendix 2.}

Cultivated taxa in the flora of Olib. Casual alien taxa sensu Richardson et al. (2000) are marked by an asterisk (*).

\begin{tabular}{|c|c|c|}
\hline $\begin{array}{c}\text { No. of } \\
\text { taxa }\end{array}$ & Taxa & Family \\
\hline 1. & Albizia julibrissin Durazz.* & Fabaceae \\
\hline 2. & Amaranthus caudatus L. & Amaranthaceae \\
\hline 3. & Apium graveolens L. & Apiaceae \\
\hline 4. & Aptenia cordifolia (L.f.) Schwantes* & Aizoaceae \\
\hline 5. & Asparagus officinalis $\mathrm{L}$. & Asparagaceae \\
\hline 6. & Atriplex halimus L. & Chenopodiaceae \\
\hline 7. & Bassia scoparia (L.) A.J.Scott* & Chenopodiaceae \\
\hline 8. & Beta vulgaris L. ssp. vulgaris & Chenopodiaceae \\
\hline 9. & Bougainvillea spectabilis Willd. & Nyctaginaceae \\
\hline 10. & Brassica oleracea L. & Brassicaceae \\
\hline 11. & Buxus sempervirens L. & Buxaceae \\
\hline 12. & Callistephus chinensis (L.) Nees & Asteraceae \\
\hline 13. & Cedrus atlantica (Endl.) Carriere & Pinaceae \\
\hline 14. & Centaurea cyanus L. & Asteraceae \\
\hline 15. & Chrysanthemum coronarium $\mathrm{L}$. & Asteraceae \\
\hline 16. & Cicer arietinum $\mathrm{L}$. & Fabaceae \\
\hline 17. & Citrus aurantium $\mathrm{L}$. & Rutaceae \\
\hline 18. & Citrus deliciosa Ten. & Rutaceae \\
\hline 19. & Citrus limon (L.) Burm. f. & Rutaceae \\
\hline 20. & Consolida ajacis (L.) Schur* & Ranunculaceae \\
\hline 21. & Cosmos bipinnatus Cav.* & Asteraceae \\
\hline 22. & Cucurbita pepo L. & Cucurbitaceae \\
\hline 23. & Cycas revoluta Thunb. & Cycadaceae \\
\hline 24. & Cynara scolymus L. & Asteraceae \\
\hline 25. & Cyperus involucratus Rottb. & Cyperaceae \\
\hline 26. & Dianthus caryophyllus L. & Caryophyllaceae \\
\hline 27. & Eriobotrya japonica (Thunb.) Lindl. & Rosaceae \\
\hline 28. & Erysimum cheiri (L.) Crantz & Brassicaceae \\
\hline 29. & Euonymus japonicus L.f. & Celastraceae \\
\hline 30. & Euphorbia marginata Pursh & Euphorbiaceae \\
\hline 31. & Fragaria $\mathrm{x}$ ananassa Duchesne & Rosaceae \\
\hline 32. & Hedera canariensis Willd. & Hederaceae \\
\hline 33. & Iberis sempervirens $\mathrm{L}$. & Brassicaceae \\
\hline 34. & Ipomoea quamoclit $\mathrm{L}^{*}$ & Convolvulaceae \\
\hline 35. & Juglans regia $\mathrm{L}$. & Juglandaceae \\
\hline
\end{tabular}




\begin{tabular}{|c|c|c|}
\hline 36. & Lantana camara L. & Verbenaceae \\
\hline 37. & Lavandula angustifolia Mill. & Lamiaceae \\
\hline 38. & Lavandula x hybrida Balb. ex Ging. & Lamiaceae \\
\hline 39. & Lippia triphylla (L' Hér.) Kuntze & Verbenaceae \\
\hline 40. & Lonicera pileata Oliv. & Caprifoliaceae \\
\hline 41. & Mesembryanthemum crystallinum L. & Aizoaceae \\
\hline 42. & Morus nigra L. & Moraceae \\
\hline 43. & $\begin{array}{l}\text { Osteospermum jucundum (E.Phillips) } \\
\text { Norl. }\end{array}$ & Asteraceae \\
\hline 44. & Paeonia lactiflora Pall. & Paeoniaceae \\
\hline 45. & $\begin{array}{l}\text { Partenocissus tricuspidata (Siebold et } \\
\text { Zucc.) Planchon }\end{array}$ & Vitaceae \\
\hline 46. & Passiflora caerulea $\mathrm{L}^{*}$ & Passifloraceae \\
\hline 47. & Pelargonium x hybridum (L.) L' Hér. & Geraniaceae \\
\hline 48. & Pelargonium zonale (L.) Aiton & Geraniaceae \\
\hline 49. & Petroselinum crispum (Mill.) A.W.Hill & Apiaceae \\
\hline 50. & Petunia hybrida Vilm.* & Solanaceae \\
\hline 51. & Phoenix dactylifera $\mathrm{L}$. & Arecaceae \\
\hline 52. & Pisum satioum $\mathrm{L}$. & Fabaceae \\
\hline 53. & Pittosporum tobira (Thunb.) Aiton $\mathrm{f}$. & Pittosporaceae \\
\hline 54. & Pointiana gilesii Hook. & Fabaceae \\
\hline 55. & Portulaca grandiflora Hooker & Portulacaceae \\
\hline 56. & Prunus avium $\mathrm{L}$. & Rosaceae \\
\hline 57. & Prunus domestica L. & Rosaceae \\
\hline 58. & Rosmarinus officinalis L. & Lamiaceae \\
\hline 59. & Salvia officinalis $\mathrm{L}$. & Lamiaceae \\
\hline 60. & Santolina chamaecyparissus L. & Asteraceae \\
\hline 61. & Solanum lycopersicum $\mathrm{L}$. & Solanaceae \\
\hline 62. & Solanum tuberosum L. & Solanaceae \\
\hline 63. & Syringa vulgaris L. & Oleaceae \\
\hline 64. & Tagetes patula $\mathrm{L}$. & Asteraceae \\
\hline 65. & Tanacetum parthenium (L.) Sch.Bip.* & Asteraceae \\
\hline 66. & Teucrium fruticans $\mathrm{L}$. & Lamiaceae \\
\hline 67. & Tilia cordata Mill. & Tiliaceae \\
\hline 68. & $\begin{array}{l}\text { Trachycarpus fortunei (Hook.) H. } \\
\text { Wendl. }\end{array}$ & Arecaceae \\
\hline 69. & Viola odorata L. & Violaceae \\
\hline
\end{tabular}

